\title{
University Students' Perceptions of Teacher Effectiveness and Emotions in Lectures: The Role of Socio-cognitive Factors, and Academic Performance
}

\author{
Georgia Stephanou (Corresponding author) \\ Doctor of Philosophy, Assistant Professor in Cognitive Psychology \\ Department of Early Childhood Education, University of Western Macedonia \\ 53100 Florina, Greece \\ E-mail: gstephanou@uowm.gr \& egokesy1@otenet.gr \\ Argyris Kyridis \\ Doctor of Philosophy, Professor in Sociology of School and Educational Practice \\ Department of Early Childhood Education, University of Western Macedonia \\ 53100 Florina, Greece \\ E-mail: akiridis@uowm.gr
}

Received: November 21, 2011 Accepted: November 30, $2011 \quad$ Published: April 1, 2012

doi:10.5539/ies.v5n2p58

URL: http://dx.doi.org/10.5539/ies.v5n2p58

\begin{abstract}
This study examined (a) students' ability self-perceptions, perceptions of domain-difficulty, value beliefs, experienced emotions in lectures and performance in the courses taught by the perceived as extremely effective and ineffective teachers, (b) the role of ability self-perceptions, perceived domain-difficulty and value beliefs in the emotions, rating of teacher effectiveness and impact of perceived teacher effectiveness on emotions, and (c) the effects of the three sets of concepts on performance. The sample comprised of 410 Early Childhood Education female students. The results showed that ability self-perceptions, perceptions of domain-difficulty, value beliefs, experienced emotions in lectures and performance differed between the courses taught by the perceived effective and ineffective teachers, in favoring the effective teachers. Cognitive factors had positive effects on perceived teacher effectiveness, emotions and impact of teacher effectiveness on emotions. The three set of concepts, together, positively influenced performance, while their relative power varied between the two groups of teachers.
\end{abstract}

Keywords: Academic performance, Emotions, Perceived teacher effectiveness, Socio- cognitive factors

\section{Introduction}

Universities pay increasing attention to effective teaching and learning (Biggs, 2003; Carnell, 2007; Ghedin \& Aquario, 2008; Marsh \& Hattie, 2002; Terenzini, 1998; Waterring \& Rijt, 2006). A major concern is how effective teachers are defined, and how teacher effectiveness is related to students' academic outcomes (Aquario, 2009; Dunkin \& Precians, 1992; Greenwald \& Gillmore, 1997; Hativa, Barak, \& Simhi, 2001; McLean \& Blackwell, 1997; Murray, 1997, 2001; Radmacher \& Martin, 2001; Sander, 2005; Stephanou \& Kyridis, 2009; Young \& Shaw, 1999). However, in spite of an expanding body of research on the positive relationship between teacher effectiveness and student achievement, there are uncertainties about to the degree to which it is influenced by individual or context factors, and the degree to which it is affected /or affects emotions (Akerlind, 2003; Pickering, 2006; Stephanou \& Kyridis, 2008). These uncertainties indicate that research between causes and effects might be challenging.

More precisely, focus on cognitive antecedents of students' rating of teacher effectiveness corresponds to current research into university teaching, and to the constructivist view of learning (Akerlind, 2003; Chalmers \& Fuller, 1996; Cuthbert, 2007; Kember \& Wong, 2000; Lizzio, Wilson, \& Simons, 2002; Stephanou, 2006a; Stephanou, Kariotoglou, Dinas, 2011; Zabaleta, 2007). Students' cognitive factors, such as ability self-perceptions, perceptions of task difficulty and value beliefs, positively influence the way that students acquire instructor data and relate it to 
existing knowledge, and, hence, may affect perceptions of teacher effectiveness (see Biggs, 1993, 1999; Stephanou, 2006a, 2011).

Also, examining the association of teacher effectiveness with student emotions is in agreement with the notion that teaching and learning involve human interaction and, therefore, has an emotional dimension (Nias, 1996; Meyer, 2009; Rosiek \& Beghetto, 2009; Schutz \& Zembylas, 2009), with the previous research evidence, documenting the important role of emotions in student life (see Efklides \& Volet, 2005; Pekrun, 2009), and with the contextualist perspective of emotions (Averill, 1997; Frijda, 2007, 2009). Teacher is an important source of student emotions in classroom learning (Astleitner, 2000; Hargreaves, 2001; Pekrun, 2005; Pekrun \& Schutz, 2007; Perry, Turner, \& Meyer, 2006; Schutz \& DeCuir, 2002; Wosnitza \& Volet, 2005). More precisely, it is the students' interpretations of the instructor's behaviour that influence how they learn and feel, not necessarily the instruction in itself (Frenzel, Pekrun, \& Goetz, 2007; Frijda, 2005; Kim, Walden, Harris, Karrass, Catron, 2007; Schutz, Hong, Cross, \& Osbon, 2006; Vermetten, Vermunt, \& Lodewijks, 2002; Stephanou, 2007; Weiner, 2002).

Furthermore, as some researches (e.g., Efklides, 2009; Frijda, 2000; Nias, 1996; Van Veen \& Lasky, 2005) support, emotion and cognition are inextricably interconnected, and, thus, both are needed to be examined to more completely understand the processes of teaching and learning. Within this perspective, recently, there is an interest in examining students' affects, and the ways in which these affects interact with cognitive, metacognitive and motivational processes as they take action in classroom (Dina \& Efklides, 2009; Do \& Schallert, 2004; Efklides, 2006a; Efklides \& Petkaki, 2005; Pekrun, Goetz, Titz, \& Perry, 2002; Schutz \& Lenehart, 2002; Turner \& Schallert, 2001). Research also focuses on how students' cognitive factors are related to their perceptions of instruction and experienced emotions in classroom. For example, previous studies showed that factors such as student's goals, values, motives, prior knowledge and perceptions of self contribute into eliciting an emotional response to a given classroom situation (Anderman \& Wolters, 2006; Goetz, Frenzel, Hall, \& Pekrun, 2008; Perry et al., 2006; Schutz \& Lenehart, 2002; Stephanou et al., 2011; Turner \& Schallert, 2001).

Also, although student emotions positively influence academic outcomes and subjective well being (Pintrich, 2003; Pekrun, 2000, 2009; Schutz \& DeCuir, 2002; Schutz et al., 2006), with the exception of test anxiety (Zeidner, 1998, 2007) and attribution-based emotions in academic achievement (Stephanou, 2003; Weiner, 1992, 2002), student emotions have been little investigated (Efklides \& Volet, 2005; Goetz, Zirngibl, Pekrun, \& Hall, 2003; Meyer \& Turner, 2002; Pekrun, 2009; Pekrun et al., 2002; Stephanou, 2006a, 2011; Wosnitza \& Volet, 2005). Similarly, although cognitive factors have each been linked to academic performance, little research has explored their interactive role with emotions in real academic achievement situations (Anderman \& Wolters, 2006; Boekaerts, Pintrich, \& Zeidner, 2000; Eccles \& Wigfield, 2002; Harackiewicz, Barron, Tauer, \& Elliot, 2002; Stephanou, 2007, 2011).

Overall, little research has examined students' experienced emotions in lectures, and the interrelations of cognition, emotions and teacher effectiveness in success in tertiary education, particularly in teacher education (Astleitner, 2000; Do \& Schallert, 2004; Meyer, 2009; Harackiewicz et al., 2002; Oosterheert \& Vermunt, 2001; Stephanou \& Kyridis, 2008; Stephanou, et al., in press). In such a context, the whole spectrum of emotions is experienced and influence academic development and subjective well-being (see Pekrun, Elliot \& Maier, 2009; Pekrun \& Stephens, 2010b; Stephanou, 2006a). This study focuses on the role of Early Childhood Education students' cognitive factors on their perceptions of teacher effectiveness, and their interactive effect on the experienced emotions in lectures, and, in turn, in academic performance in the courses taught by the perceived effective and ineffective teachers.

This study is based on Pekrun's (2006) control-value theory of achievement emotions, Wigfield and Eccles's (2000) expectancy-value model of motivation, and teacher effectiveness literature (see Carnell, 2007; Marsh \& Hatie, 2002; Stephanou, 2006b; Stephanou \& Kyridis, 2009; Young \& Shaw, 1999; Zabaleta, 2007).

According to Pekrun's theory, the emotions experienced in academic settings can be classified into four major categories as to whether they are positive activating emotions, positive deactivating emotions, negative activating emotions and negative deactivating emotions (Pekrun, 1992, 2009; Pekrun et al, 2002). Positive emotions are typically pleasant, sought after, or appreciated. Negative emotions are typically unpleasant, not actively pursued, and avoided. Activating emotions (e.g., hope, enjoyment of learning) are those that push the student to act or to be engaged in a task. Deactivating emotions (e.g., hopelessness, boredom), in contrast, influence the student to rest, disengaged or avoid a task. In addition, certain emotions (e.g., hope, anxiety) are derived from the self or the task, academic learning processes-related emotions (e.g., excitement, joy, or boredom) derived from the actual completion of the task, while academic achievement- related emotions (e.g., as pride or shame) occur after task achievement. Finally, social emotions are formulated from the interaction with the others (e.g., admiration, envy), or that directed at others (e.g., anger). Overall, control- related (e.g., expectancy beliefs, competence beliefs) cognitions 
and subjective values- related (e.g., goals, importance) beliefs are the most significant antecedents of students' academic emotions. These cognitive appraisals mediate the associations of emotions with social (e.g., teacher) environment, with respect, mainly, to competence support, autonomy support versus control, expectations and goal structures, achievement outcomes and feedback, and social relatedness.

The expectancy-value model of motivation (Eccles \& Wigfield, 2002; Wigfield \& Eccles, 2000) suggests that task value and expectancy beliefs are the most significant formulators of achievement behaviour. Expectancy is defined as one's expectation for future success and is related to one's competence beliefs. Value refers to the importance, cost and the interest of the task. Value and expectancy is mainly related to academic choice and performance, respectively. These two sets of beliefs are influenced by task specific self-concept and task difficulty beliefs. The self-concept belief is student's perceptions of his / her ability to do a task, while task difficulty belief represents the student's judgments of the difficulty of the task.

\subsection{Relationships among Students' Perceptions of Teacher Effectiveness, Emotions, Cognitive Factors and Academic performance}

Three areas of research are relevant to relationship of instruction with students' emotions: Students' well-being (Diener, 2000; Hascher, 2003), anxiety (Zeidner, 1998, 2007) and quality of instruction (see Glaser-Zikuda, Fub, Laukenmann, Metz, \& Randler, 2005; Vauras, Salonen, Lehtinen, \& Kinnunen, 2009). Investigation on instruction has consistently supported that teacher's instructional and other behaviour is an important source of students' emotions in classroom learning (Davis, 2003; Furrer \& Skinner, 2003; Jarvenoja \& Jarvela, 2005; Rodger, Murray, \& Cummings, 2007; Rosiek \& Beghetto, 2009; Stephanou, 2007, 2011). For example, teachers' didactic competence and social interactions have an effect on students' well being, and aspects of instruction, such as lack of transparency of achievement expectations and lack of feedback, have an impact on test anxiety. Similarly, teacher-centrered instruction does not facilitate emotional aspects of learning (Schutz \& Lenehart, 2002; Weiner, 2002). In contrast, teacher's high learning goals influence students' adoptions of high personal goals, and offering positive feedback and displaying positive emotions support students' motivation for learning (Anderman, Patrick, Hiruda, \& Linnenbrink, 2002; Pintrich \& Schunk, 2002). However, as above mentioned, it is the students' perceptions of instruction and their evaluation of the learning process that influence how they learn and feel, not necessarily the instruction in itself (Brok, 2001; Davidson \& Phelan, 1999; Frenzel et al., 2007; Schutz \& Lenehart, 2002; Stephanou \& Kyridis, 2008; Weiner, 2001, 2002; Wentzel, 1998, 2002; Zimmerman \& Schunk, 2001). More precisely, the appraisal of a certain learning situation is influenced by self-beliefs (Frijda, 2009; Stephanou, 2005, 2006b; Weiner, 2002, 2005). Cognitions are the most significant antecedents of students' evaluation of instruction and emotions in the classroom (Goetz et al., 2003; Pekrun, 2009; Pekrun et al., 2002; Stephanou, 2006a, 2011). For example, the students, who have high competence and value beliefs, compared to students, who are less favour in the respective factor, perceive the instructor as more effective and experience more positive emotions in classes in secondary and tertiary education (Kususanto, Ismail, \& Jamil, 2010; Stephanou, 2006a, 2007, 2011; Stephanou et al., 2011).

Generally, previous researches on the relationship of cognition with emotions in educational context, on one hand, supported positive effects of cognitive factors on emotions. For example, expectations of high achievement, beliefs of ability to master the task and attached high value to task create the feeling of pleasure (Glaser-Zikuda et al., 2005; Glaser-Zikuda \& Mayring, 2003; Linnenbrink \& Pintrich, 2000; Pekrun, 2000). Similarly, engagement in an interest activity or high valuable task produces positive feelings such as enjoyment (Anderman \& Wolters, 2006; Stephanou, 2006a, 2007). In contrast, beliefs of inadequate ability in accomplishment the task, expectations of low performance and lack of interest in the task contribute into forming the feelings of hopelessness and anxiety (Pekrun et al., 2002; Stephanou, 2004b; Zeidner, 1998, 2007). Also, perceived task-difficulty influences task- and future activityemotions like boredom, enthusiasm and confidence (Efklides, 2006a,b; Pekrun, 2006, 2009; Pekrun \& Schutz, 2007). Other studies suggest that the effect of mood on behaviour is influenced by how the individuals interpret negative information about themselves (Efklides, 2006b; Efklides \& Petkaki, 2005; Siemer, Mauss \& Gross, 2007; Trope, Hassin, \& Gervey, 2001; Turner, Thorpe, \& Meyer, 1998). More precisely, students, with failure academic experience, which is usually related to low self-concept, tent to experience negative mood, when they face negative information about themselves. This negative mood, along with low success expectations, lead to avoidance of challenging task, low effort, and, thus, minimizing of capabilities.

On the other hand, emotions influence cognitive information processing, quality of thinking, motivation, learning strategies, self- regulation, metacognition, and achievement (Boakaerts et al., 2000; Efklides \& Volet, 2005; Kuhbandner, Hanslmayr, Maier, Pekrun, Spitzer, Pastötter, \& Bäuml, 2009; Pekrun, Goetz, Daniels, Stupnisky, \& Perry, 2010). For example, positive emotions, such as curiosity, enjoyment, hope and pride, enhance motivation, facilitate learning and increase performance (Clore \& Huntsinger, 2009; Meyer \& Turner, 2002; Pekrun et al., 2002; 
Stephanou, 2006a, 2007), while intense negative emotions, like anxiety, hopelessness, boredom and insecurity, and related thoughts, like a feeling of incompetent, interface with learning, decrease motivation and performance, and affect the decision to withdraw from academic courses (Goetz et al., 2003; Kuyper, van der Werf, \& Lubbers, 2000; Pekrun et al., 2010; Zeidner, 2007). In addition, research, based on Pekrun's (2002, 2009) model, reported a wide range of academic emotions, that is, emotions related to academic achievement (such as pride or shame) and academic learning processes (such as excitement, joy, or boredom) (see Efklides \& Volet, 2005; Pekrun, Frenzel, Goetz, \& Perry, 2007; Pekrun \& Stephens, 2010a; Stephanou, 2007; Stephanou et al., 2011).

The findings from previous researches regarding the role of perceived self-factors in academic achievement supported the positive role of ability self-perceptions on performance, even after controlling for ability (Beane, 1999; Pintrich \& Schunk, 2002; Stephanou, 2003, 2008), the positive association of perceived task-difficulty with the academic performance, since it facilitates the awareness of the process in pursuit the target goal and correlates strongly with self-regulatory process (Dina \& Efklides, 2009; Efklides, 2006a; Zimmerman \& Schunk, 2001; Stephanou, 2011), and the association of students' high value beliefs with enjoyment, high effort in pursuing the goals, successful performance, and future academic choices (Bruinsma, 2004; Eccles, Barber, Updegraff, \& O' Brien, 1998; Eccles \& Wigfield, 2002; Stephanou, 2004a,b, 2008; Stephanou \& Tatsis, 2008).

Research on teacher effectiveness in tertiary education supports a positive relationship between students' ratings of teacher effectiveness and their academic performance, particularly in unsuccessful one (see Eiszler, 2002; Greenwald \& Gillmore, 1997; Hativa et al., 2001; Marks, 2000; Marsh \& Rochi, 2000; Murray, 1997, Nasser \& Fresko, 2006; Stephanou \& Kyridis, 2009).

\subsection{Aim of the Study - Hypotheses}

This study aimed to examine (a) students' ability self-perceptions, perceptions of domain-difficulty, value beliefs and experienced emotions in lectures in courses taught by the perceived extremely effective teachers and ineffective teachers, (b) the role of students' ability self-perceptions, perceptions of domain-difficulty and value beliefs in the generation of the same emotions and rating of teacher effectiveness, and in the impact of rating of teacher effectiveness on the emotions, (c) the relations of students' experienced emotions in lectures, ability self-perceptions, perceptions of domain-difficulty, value beliefs and rating of teacher effectiveness with academic performance in the courses taught by the perceived extremely effective teachers and ineffective teachers, and (d) the effects of the cognitive factors on the interactive impact of rating of teacher effectiveness and emotions on academic performance in the courses taught by the perceived extremely effective and ineffective teachers.

\section{The hypotheses of the study were the following:}

Students will experience various, and a variety of intensity, of emotions (mainly, self-, social-, context- and taskrelated) in the lectures of the courses, but there will be differences in their prevalence within and between the perceived effective and ineffective teachers groups (Hypothesis 1a). The students will experience more positive emotions (mainly, social-, context- and task-related) in the lectures of the courses taught by the perceived effective teachers than in the lectures of the courses taught by the perceived ineffective teachers (Hypothesis 1b). There will be differences in students' cognitive factors within each group of teachers (perceived effective / ineffective) (Hypothesis 2a). The students will have higher value beliefs, lower domain-difficulty perceptions, and, mainly, higher ability self-perceptions in the courses taught by the perceived effective teachers than in the courses taught by the perceived ineffective teachers (Hypothesis 2b). Students' cognitive factors will positively influence the generation of their rating of teacher effectiveness, their experienced emotions in lectures and the impact of rating of teacher effectiveness on the emotions, mainly in the perceived ineffective teachers group (Hypothesis 3a). However, their predictive strength will vary between and within the perceived effective / ineffective teachers groups (Hypothesis 3b). Students' rating of teacher effectiveness will have positive impact on the generation of the emotions (mainly, social-, context- and task- related), particularly in the group of the perceived ineffective teachers (Hypothesis 4). Students' cognitive factors (predominately, ability self-perceptions), rating of teacher effectiveness and emotions (particularly, self-, expectancy- and future behaviour- related) will positively influence the generation of their performance in the courses taught by the perceived effective teachers and, mainly, ineffective teachers (Hypothesis 5a). Cognitive factors will mediate the interactive effect of rating of teacher effectiveness and emotions on academic performance (Hypothesis $5 b$ ).

\section{Method}

\subsection{Participants}

A total of 410 Early Childhood Education female students, age 19-23 years (Mean $=20.82$ years, $\mathrm{SD}=1.64$ ) participated into this study. They were $2 \mathrm{nd}(\mathrm{n}=140)$, 3rd $(\mathrm{n}=146)$ and 4 th $(\mathrm{n}=124)$ year students, and they 
randomly came from four Greek universities. Due to the nature of Early Childhood Education studies, the sample of this investigation comprised only female students.

\subsection{Measures}

A questionnaire with separate versions for the perceived extremely effective teacher and the perceived extremely ineffective teacher was constructed. The questionnaire was based on previous research (see Eccles \& Wigfield, 2002; Park, Crocker, \& Kiefer, 2007; Pekrun et al, 2002; Pintrich \& Schunk, 2002; Stephanou, 2006a,b, 2007, 2008; Stephanou et al., 2011; Young \& Shaw, 1999; Weiner, 1992, 2002; Wigfield \& Eccles, 2000). The wording of the questions for the two teachers was the same except for the teacher name (effective / ineffective).

Students' Perceived teacher effectiveness was measured via the 25 -item Students' Perceived Teacher Effectiveness Scale (Young \& Shaw, 1999). The scale measures many constructs of teacher effectiveness (e.g., "The instructor was knowledgeable about subject matter", "The instructor was enthusiastic about teaching", "The instructor was able to explain material clearly"). All items are rated from 1 (not at all descriptive) to 9 (very descriptive). The scale is a valid and reliable instrument in examining university students' perceptions of teacher effectiveness in Greek population (see Stephanou, 2006a, b; Stephanou \& Kyridis, 2009). This study focuses on students' rating of teacher total effectiveness, and not on specific components of effectiveness. Cronbach's alphas were .79 for the perceived effective teachers group, and .80 for the perceived ineffective teachers group.

The Value Beliefs scale comprised four questions (e.g., "How much do you value the courses taught by the extremely effective teacher?", "How valuable are the courses taught by the extremely effective teacher for you?"). Responses ranged from $1=$ not at all to $7=$ very much. Gronbach's alphas were .82 and 80 for the perceived effective teachers group and ineffective teachers group, respectively.

The Ability Self-perception scale consisted of six questions (e.g., "How good do you think you are in the courses taught by the extremely ineffective teacher?", "How good are you in the courses taught by the extremely ineffective teacher?"). Responses ranged from $1=$ not at all good to $7=$ excellent. Cronbach's alphas were .85 and .81 for the perceived effective teachers group and ineffective teachers group, respectively.

The Perceived Domain-difficulty scale comprised five questions (e.g., "How difficult are the courses taught by the extremely effective teacher for you?"). Responses ranged from $7=$ not at all difficult to $1=$ very difficult. Cronbach's alphas were .80 for the perceived effective teachers group, and .83 for the perceived ineffective teachers group.

The scale of Students' Experienced Emotions in the lectures of the courses consisted of seventeen emotions, happiness, pleasure, satisfaction, cheerfulness, not irritated-irritated, pride, encouragement, not anxiety-anxiety, boredom-not boredom, interest, hope, confidence, competence, not angry-angry, excitement, enthusiasm, and calmness. The students were asked to indicate the extent to which they usually experienced each of the emotions in the lectures of the courses taught by the extremely effective or ineffective teacher. The emotions had the form of opposite adjectives, with the positive one having the high score of 7 and the negative adjective having the low score of 1 (e.g., happy 7654321 unhappy).

Students' Academic performance in the courses taught by the specific teachers were indicated by the students themselves (from $1=$ very poor to $10=$ excellent). Students were asked to indicate the courses they taught by the effective teacher and ineffective teacher, each course grade, and the mean grade in these specific courses.

The participants' Personal information scale consisted of a set of questions relevant to personal factors, such as age, gender and academic semester.

\subsection{Research Design and Procedure}

Students were asked to select two teachers from whom they had taken course in the university up to the moment of this research; a teacher who, in their judgment, was extremely effective, and a teacher who, in their judgment, was extremely ineffective. They also were emphasized to choice teachers whom they could recall in details. The participants were provided with separate questionnaires for the most effective teacher and the most ineffective teacher. The wording of the questions of the scales for the two teachers was the same except for the effectiveness (effective / ineffective). The students were informed, written and orally, the aim of this research, and they assured of anonymity and confidentiality. The participants completed the questionnaires at their Department, in front of the researchers' co-workers, who were female postgraduate students and had trained for this particular part of the research by the investigators. To match the questionnaires that were responded by the same student, students were asked to choose a code name and use it on the response sheets. To minimize the chances of recalling teachers from the recent past academic semester, because of the academic achievement, particularly the unexpected failure, the data were collected in the middle of winter (first) academic semester. Data collection was completed within two 
weeks. Also, to ensure that any relation between emotions and the other variables was not due to procedure used, students completed first the emotions scale and then the rest of the scales.

\section{Results}

\subsection{Differences between the Perceived Effective and Ineffective Teachers Groups with Respect to Students'Emotions, Ability Domain Self-perceptions, Value Beliefs and Perceived Domain-difficulty}

To examine the differences between the intensity of the experienced emotions in the lectures of the courses within the perceived effective teachers and ineffective teachers, two repeated Anova analyses were conducted, one for each group of teachers, in which the students' emotions was the repeated factor. The results showed that the students experienced a variety of emotions, and a variation of intensity of emotions, in the lectures of the courses taught by the perceived effective teachers, $\mathrm{F}(17,393)=44.80, \mathrm{p}<.01, \eta^{2}=.66$, and in the lectures of the courses taught by the perceived ineffective teachers, $F(17,393)=51.80, p<.01, \eta^{2}=.70$. More precisely, the mean scores and post hoc pairwise comparisons revealed that the students' most intense positive emotions were pleasure, not boredom, excitement, not irritated, not anger and enthusiasm in the effective teachers group. In contrast, not excitement, not interest, boredom, dissatisfaction and anxiety were the most intensive negative emotions which were experienced by the students in the ineffective teachers group (Table 1).

The findings from ANOVAs, with the perceived (effective/ineffective) teacher as between subjects factor, and examination of the mean scores of emotions revealed that the students felt better in the lectures of the courses taught by the perceived effective teachers than in the lectures of the courses taught by the perceived ineffective teachers. In addition, Discriminat analysis, with stepwise method, was performed to find the set of emotions that best discriminated the two groups of teachers (Table 1). The students' experienced emotions in the lectures of the courses were the predictor variables, and the perceived effective/ineffective teacher was the grouping variable. The results confirmed the univariate effects and, in addition, showed that, $94 \%$ of the teachers were correctly classified into groups of effective and ineffective teachers, and that the emotion of pleasure, discriminating power $=.76$, Cohen's $d$ $=.1 .59$, followed by the emotions of excitement, discriminating power $=.73$, Cohen's $d=1.57$, not boredomboredom, discriminating power $=.67$, Cohen's $\mathrm{d}=1.53$, interest, discriminating power $=.62$, Cohen's $\mathrm{d}=1.46$, enthusiasm, discriminating power $=.62$, Cohen's $d=1.47$, not irritated - irritated, discriminating power $=.61$, Cohen's $\mathrm{d}=1.45$, hope, discriminating power $=.58$, Cohen's $\mathrm{d}=1.40$, calmness, discriminating power $=.58$, Cohen's $d=1.39$, and confidence, discriminating power $=.54$, Cohen's $d=1.37$ (Note 1 ), was the most powerful factor in discriminating the perceived effective teachers group from the perceived ineffective teachers group. However, the emotions of happiness, satisfaction, encouragement, anger-not anger, cheerfulness and competence had no significant contribution in separating the two groups of teachers.

The above findings partly confirmed Hypotheses $1 \mathrm{a}$ and $1 \mathrm{~b}$.

Table 1 about here

The repeated measures ANOVAs, examining differences between the three cognitive factors within each group of the perceived teachers (effective / ineffective), showed a significant effect in both groups of the teachers, effective, $F$ $(2,408)=197.28, \mathrm{p}<.01, \eta^{2}=.49$, and ineffective, $\mathrm{F}(2,408)=396.35, \mathrm{p}<.01, \eta^{2}=.66$. Inspection of the mean scores and the post hoc pairwise comparisons showed that the students, in both groups of the teachers, had higher value beliefs than perceptions of self-ability and domain difficulty, and estimated their ability higher than domain difficulty. The findings from ANOVAs, with the rating teacher effectiveness (effective / ineffective) as between-subjects factor, revealed significant effect in each of the three factors. The results from Discriminant analyses, with stepwise method, confirmed the univariate effects and, in addition, showed that $80 \%$ of the teachers were correctly classified into groups of effective and ineffective teachers, and that ability self-perception, $\mathrm{F}(1,818)$ $=251.35, \mathrm{p}<.01$, Cohen's $\mathrm{d}=.95$, discriminating power $=.89$, followed by perceived domain-difficulty, $\mathrm{F}(1,798)=$ $235.10, \mathrm{p}<.01$, Cohen's $\mathrm{d}=.90$, discriminating power $=.86$, and value beliefs $\mathrm{F}(1,818)=25.00, \mathrm{p}<.01$, Cohen's $\mathrm{d}$ $=.32$, discriminating power $=.28$, was the most powerful factor in discriminating the two groups of teachers. Examination of the mean scores indicated the students estimated their ability as higher $(\mathrm{M}=6.09, \mathrm{SD}=.80)$, perceived the academic domain as less difficult $(\mathrm{M}=5.57, \mathrm{SD}=1.29)$, and had higher value beliefs $(\mathrm{M}=6.57$, $\mathrm{SD}$ $=.72$ ) for the courses taught by the perceived effective teacher than for the taught courses (ability self-perceptions: $\mathrm{M}=4.73, \mathrm{SD}=1.51$, domain difficulty: $\mathrm{M}=3.90, \mathrm{SD}=1.73$, value beliefs: $\mathrm{M}=6.29, \mathrm{SD}=.83$ ) by the perceived ineffective teachers.

The above findings confirmed Hypotheses $2 \mathrm{a}$ and $2 \mathrm{~b}$.

3.2 Effects of Socio-cognitive Factors on Emotions, Rating of Teacher Effectiveness, Impact of Rating of Teacher Effectiveness on Emotions, and, in Turn, on Academic Performance in Association to Perceived Effective / 


\section{Ineffective Teachers}

\subsubsection{Effects of Socio-cognitive Factors on Rating of Teacher Effectiveness}

The results from correlation coefficient analyses (Table 2) supported our expectations that there will be significant and positive correlations between students' socio-cognitive factors and their rating of teacher effectiveness in the perceived effective and ineffective teachers groups. However, the magnitude of the effects of the cognitive factors on rating of teacher effectiveness partly confirmed our expectations, as the multiple regression analyses, with the rating of teacher effectiveness as predicted variable and the three cognitive factors as predictors, revealed. Specifically, the three cognitive factors, as a group, explained a greater amount of the variability in rating of teacher effectiveness in the perceived effective teachers group, $\mathrm{R}^{2}=.61, \mathrm{~F}(3,406)=81.00, \mathrm{p}<.01$, than in the perceived ineffective teachers group, $\mathrm{R}^{2}=.12, \mathrm{~F}(3,406)=18.50$. Also, in the perceived effective teachers group, ability self perception, $\mathrm{b}=.36, \mathrm{t}(409)=6.50, \mathrm{p}<.01$, was the most powerful predictor of teacher effectiveness, followed by value beliefs, $\mathrm{b}=.30, \mathrm{t}(409)=5.70, \mathrm{p}<.01$, while perceived domain difficulty was not a significant contributor. In the perceived ineffective teachers group, only ability self-perceptions had a unique contribution into rating of teacher effectiveness, $\mathrm{b}=.60, \mathrm{t}(409)=7.85, \mathrm{p}<.01$. These findings are partly in agreement with Hypothesis 3 with respect to effect of cognitive factors on rating of teacher effectiveness.

\subsubsection{Effects of Socio-cognitive Factors and Rating of Teacher Effectiveness on Emotions}

In addition to correlation coefficient analyses (Table 2), a series of hierarchical regression analysis were conducted to examine the role of students' cognitive factors (ability self-perceptions, perceived domain-difficulty and value beliefs) and rating of teacher effectiveness on their experienced emotions in the lectures of the courses taught by the perceived extremely effective teachers and the perceived extremely ineffective teachers, and the role of the cognitive factors in the impact of rating of teacher effectiveness on the emotions. Each of the emotions was the criterion variable, and rating of teacher effectiveness and cognitive factors entered at the first and second step of the analysis, respectively (Table 3). The results from these analyses showed that the two sets of predictors, together, had significant and positive effect in the formulation of most of the students' emotions (mainly, task- expectancy- and future behaviour- related), explaining an amount of variance of emotions from $21 \%$ (encouragement) to $53 \%$ (enthusiasm) in the perceived effective teachers group, and from 16\% (sadness) to $57 \%$ (non confidence) in the perceived ineffective teachers group. Furthermore, the self (pride)- goal (satisfaction)- and future behaviour (hope, confidence)- related emotions were best explained by the predictors in the perceived effective teachers group than in the perceived ineffective teachers group, while the opposite pattern was found for the context-, task- and future activity (boredom-not boredom, excitement, cheerfulness)- related emotions.

Inspection of the results in Tables 2 and 3 also indicated that the higher the students' rates of teacher effectiveness the higher the intensity of their positive emotions (mainly, excitement, hope, pride and enthusiasm) in the lectures of the courses taught by the perceived effective teachers. In contrast, the higher the students' rates of teacher ineffectiveness the higher the intensity of their negative emotions (mainly, boredom, hopelessness, no confidence, no enthusiasm, and not excitement) in the lectures of the courses taught by the perceived ineffective teachers. More precisely, students' perceptions of teacher effectiveness, before the entry of the students' beliefs in the equitation of the analyses, explained an amount of variance of their experienced emotions in the lectures, in the effective teachers group, from .06 (satisfaction, not anxiety) to .38 (enthusiasm), and, in the ineffective teachers group, from .05 (irritation, incompetence) to .29 (boredom, hopelessness). Yet, the rating of teacher effectiveness, in the perceived effective teachers group, had unique effect on the generation of seven emotions, with beta ranging from .10 for not boredom to .24 for enthusiasm, and, in the perceived ineffective teachers group, had significant contribution into the generation of all of the emotions, beta ranged form .23 for sadness and .28 for irritation to .55 for not enthusiasm, .56 for hopelessness, .58 for boredom and .61 for non confidence.

The findings regarding the cognitive factors were in the main as expected. More precisely, the students, who had higher value beliefs, higher ability self-perceptions and lower perceptions of the difficulty of the academic domain, in comparison to the students, who estimated the respective factor less favourite, experienced intense positive emotions (mainly, self-, context- and task- related) in the lectures of the courses taught by the perceived effective teachers. In contrary, the formers, as compared to the latter ones, experienced less intense negative emotions (mainly, self-, expectancy- and future behaviour- related) in the lectures of the courses taught by the perceived ineffective teachers. Also, the relative power of the three factors in predicting emotions varied between and within perceived effective / ineffective teachers. Specifically, in the perceived effective teachers group, value beliefs (beta ranged from .18 for calmness to. 63 for both hope and competence), proved the most powerful predictor of all of the emotions, except for pleasure (beta $=.41)$, interest (beta $=.47)$, anxiety (beta $=.50)$ and encouragement $($ beta $=.29)$, which were best predicted by the perceived domain difficulty, and for confidence (beta $=.26$ ), which was best 
predicted by ability self-perceptions. In addition, perceived domain difficulty (beta ranged from .10 for non irritation to .50 for non anxiety), as compared to ability self-perceptions (beta ranged from .12 for non boredom to .34 for competence and .37 for enthusiasm), predicted the emotions better, whereas the opposite pattern was found in satisfaction, pride, confidence, non anger, non irritation, cheerfulness, competence and enthusiasm. In the perceived ineffective teachers group, the perceived domain-difficulty (beta ranged from .33 for discouragement though .64 for both non confidence and anxiety to .66 for both irritation and non satisfaction) proved the most powerful predictor of the emotions, with the exception being in the emotions of non enthusiasm and non confidence (beta $=.53$ ), which were mainly generated by ability self-perceptions, and in the emotions of discouragement (beta $=.38$ ), incompetence (beta $=.61$ ) and non excitement (beta $=.51$ ) that were predominately generated by value beliefs. Additionally, ability self-perceptions (beta ranged from .13 for hopelessness to .53 for both non enthusiasm and non confidence), compared to value beliefs (beta ranged from .16 for anxiety to .61 for incompetence), was a more powerful formulator of the emotions, while the opposite pattern was evidenced for the emotions of discouragement, not interest, hopelessness, incompetence, non excitement and boredom.

Furthermore, the students' cognitive factors mediated the impact of their rating of teacher effectiveness on most of their experienced emotions in the lectures of the courses taught by the perceived effective teachers, $\mathrm{R}^{2} \mathrm{ch}$ ranged from .12 (encouragement), through .39 (both competence and excitement), to .41 (not boredom), and in the lectures of the courses taught by the perceived ineffective teachers, $\mathrm{R}^{2} \mathrm{ch}$ ranged from .12 (sadness, boredom), through .32 (non confidence) and .31 (shame), to .36 (incompetence). Additionally, cognitive factors influenced the impact of the perceived teacher effectiveness on the emotions more in the effective than in the ineffective teachers group, while the reverse was the case with respect to the emotions of satisfaction, pride and encouragement.

The above findings partly confirmed Hypotheses 3 and 4.

Table 2 about here

Table 3 about here

\subsubsection{Effects of Socio-cognitive Factors, Rating of Teacher Effectiveness and Emotions on Academic Performance}

The students achieved higher academic performance in the courses taught $(\mathrm{M}=8.32, \mathrm{SD}=1.40)$ by the perceived effective teachers than in the courses taught $(\mathrm{M}=6.02, \mathrm{SD}=.95)$ by the perceived ineffective teachers, $\mathrm{t}(1,409)=$ $136.00, \mathrm{p}<.01$, Cohen's $\mathrm{d}=1.28$.

The presented results in Table 2 indicate that the students' cognitive factors, experienced emotions in the lectures and rating of teacher effectiveness were significantly related to their performance in the courses taught by both groups of teachers. More precisely, better the students felt (mainly, self-, general- and performance- related emotions: pride, competence, confidence and happiness) in the lectures of the courses, more positively they estimated their cognitive (particularly, ability) factors and higher they rated their teachers' effectiveness, higher academic performance they achieved in the courses taught by the perceived effective teachers. In contrast, worse the students felt in the lectures of the courses (particularly, general-, expectancy-, performance- and task- related emotions: dissatisfaction, displeasure, hopelessness, boredom and non confidence), lower they estimated their cognitive factors (mainly, domain difficulty) and lower they rated their teachers' effectiveness, lower performance they achieved in the courses taught by the perceived ineffective teachers.

Furthermore, as the results from hierarchical regression analyses, with the students' experienced emotions in the lectures of the courses at the first step, rating of teacher effectiveness at the second step and cognitive factors at the third step, indicated, the three sets of predictors, in combination, explained a significant portion of variance of performance in the courses taught by the perceived effective teachers, $\mathrm{R}^{2}=.32, \mathrm{~F}(21,388)=8.45, \mathrm{p}<.01$, and, mainly, in the courses taught by the perceived ineffective teachers, $\mathrm{R}^{2}=.55, \mathrm{~F}(21,388)=24.00, \mathrm{p}<.01$. However, the prevalence of the predictors varied within and between the two groups of teachers.

Specifically, the findings regarding the perceived effective teachers group revealed that: (a) emotions, before the entry of the other two sets of predictors into analysis, explained $30 \%$ of the variability of academic performance, $\mathrm{F}(17,392)=9.87, \mathrm{p}<.01$, (b) emotions and rating of teacher effectiveness, in combination, explained $31 \%$ of performance, $F(18,391)=9.55, \mathrm{p}<.01$, (c) rating of teacher effectiveness did not enhance the effects of emotions on academic performance, $\operatorname{Rch}^{2}=.006, \operatorname{Fch}(1,391)=3.00, \mathrm{p}>.05$, whereas cognitive factors mediated the impact of the other two sets on academic performance, $\operatorname{Rch}^{2}=.015, \operatorname{Fch}(3,388)=3.00, \mathrm{p}<.05$, and (d) pride, $\mathrm{b}=.17, \mathrm{t}=$ $2.95, \mathrm{p}<.01$, hope, $\mathrm{b}=.16, \mathrm{t}=3.28, \mathrm{p}<.01$, enthusiasm, $\mathrm{b}=.15, \mathrm{t}=3.10, \mathrm{p}<.01$, competence $. \mathrm{b}=14, \mathrm{t}=3.05, \quad \mathrm{p}$ $<.01$, and ability self-perceptions, $\mathrm{b}=.23, \mathrm{t}=4.00, \mathrm{p}<.01$, contributed uniquely to the generation of academic performance.

The findings regarding the perceived ineffective teachers group showed that: (a) the experienced emotions in the 
lectures of the courses, before the entry of the other two sets of predictors into analysis, explained $52 \%$ of the variability of academic performance, $\mathrm{F}(17,392)=25.16, \mathrm{p}<.01$, (b) emotions and rating of teacher effectiveness, as a group, explained $54 \%$ of the variance of academic performance, $F(18,391)=26.42, p<.01$, (c) rating of teacher effectiveness mediated the effects of emotions on academic performance, $\operatorname{Rch}^{2}=.019, \operatorname{Fch}(1,391)=16.00, p<.01$, whereas the entry of cognitive factors at the analysis did not increase the effects of the other two sets of predictors on academic performance, $\operatorname{Rch}^{2}=.002, \operatorname{Fch}(3,388)=.65, \mathrm{p}>.05$, and (d) dissatisfaction, $\mathrm{b}=.56, \mathrm{t}=910.35, \mathrm{p}$ $<.01$, no confidence, $\mathrm{b}=.10, \mathrm{t}=2.35, \mathrm{p}<.05$, incompetence, $\mathrm{b}=.14, \mathrm{t}=2.45, \mathrm{p}<.05$, non excitement, $\mathrm{b}=.09, \mathrm{t}=$ $2.26, \mathrm{p}<.05$, and rating of teacher effectiveness, $\mathrm{b}=.16, \mathrm{t}=3.70, \mathrm{p}<.01$, had unique effect on the formulation of academic performance.

The above findings were in the main in agreement with Hypotheses $5 \mathrm{a}$ and $5 \mathrm{~b}$.

\section{Discussion}

This study aimed to examine (a) possible differences in students' value beliefs, ability self-perceptions, perceived domain-difficulty and experienced emotions in lectures in courses taught by the perceived effective and ineffective teachers, (b) the role of the cognitive factors in students' rating of teacher effectiveness and emotions, and in the impact of rating of teacher effectiveness on emotions in both groups of teachers, and (c) and the interactive effect of the three sets of concepts on semester performance in the courses taught by the two groups of teachers.

\subsection{Discussion of the Findings in Association to Respective Literature and Hypotheses}

\subsubsection{Students' Emotions}

In line with previous researches, documenting the variety of students' classroom emotions and their sources (see Efklides \& Volet, 2005; Jarvenoja \& Jarvela, 2005; Pekrun et al., 2002; Stephanou, 2006a, Stephanou et al., 2011; Vauras, Salonen, \& Kinnunen, 2008; Weiner, 2002, 2005), the present study reported that the students experienced various emotions in the lectures of the courses taught by the perceived effective and ineffective teachers.

The high intensity of context- and other- directed emotions supported previous research evidence about the female students' sensitivity to classroom context and their need of support by significant others, such as teachers (Frenzel et al., 2007; Hativa et al., 2001; Stephanou, 2006a; Stephanou \& Kyridis, 2009; Turner \& Meyer, 2000). This specific finding is also in agreement with other investigations, reporting the early childhood students' preferences for teachers with field dependent characteristics than teachers with field independent characteristics (see Stephanou, 2006b). Overall, this result underlines the higher education students' need for support and interaction in classroom learning, as previous studies have shown (Carnell, 2007; Lizzio et al., 2002; Vermetten et al., 2002).

The fact that students' experienced task- and self-esteem- related emotions in lectures is in agreement with the notion that students' emotional experience during learning is influenced by their self-perceptions, and by situational, and motivation for the task factors (Fredrickson, 2001; Pekrun et al., 2002). Furthermore, since tertiary education emphasizes academic performance, probably the students, during lectures, estimate self- factors in pursuing such a goal (see Anderman \& Wolters, 2006; Perry et al., 2006; Schutz \& Lenehart, 2002; Pekrun et al., 2009; Pekrun \& Stephens, 2009).

The findings from the present study also, confirming previous researches (see Frenzel et al., 2007; Frenzel, Goetz, Lüdtke, Pekrun, \& Sutton, 2009; Pekrun et al., 2010; Stephanou, 2006a; Stephanou et al., 2011; Weiner, 2002, 2005), supported the crucial role of students' perceptions of teacher effectiveness on their experienced emotions in the lectures of the courses. Specifically, the perceived teacher effectiveness differentiated the prevalence of the students' experienced emotions in lectures between the courses taught by the perceived effective teachers and ineffective teachers, and within each group of teachers. More precisely, as expected, the students experienced intense positive emotions, mainly task-, context-, future activity- and other- related (pleasure, not boredom, excitement, not irritated, not anger, enthusiasm), in the lectures in the courses taught by the perceived effective teachers, whereas they experienced negative emotions, particularly task-, context-, goal- and performance- related (not excitement, not interest, boredom, dissatisfaction and anxiety), in lectures in the courses taught by the perceived ineffective teachers. In addition, pleasure, followed by task-, future activity and future behaviour- (i.e., excitement, not boredom-boredom, interest, enthusiasm, hope, confidence) related emotions, was the most powerful factor in discriminating the perceived effective teachers group from the perceived ineffective teachers group. Furthermore, students' rating of teacher effectiveness contributed into generation of their experienced emotions (mainly, achievement-, expectancy- and future behavour- and activity- related) in the lectures in the courses taught by the perceived effective teachers and, predominately, ineffective teachers, even after controlling for cognitive factors.

It seems that the students did not enjoy classes and focused on themselves and their goals in the lectures of the courses taught by the perceived ineffective teachers. The students, probably, appraised the status of self- factors in 
pursuing their goals that include performing well in the exams, since such emotions are experienced in relationship to goals (Carver \& Scheier, 2000; De la Fuente, 2004; Frijda, 2005, 2009; Linnenbrink \& Pintrich, 2002 Pekrun \& Stephens, 2010a). However, the nature of these emotions (hopelessness, dissatisfaction, not enthusiasm, not confidence) may 'remove' or 'distance' the students from the objects (see, Frijda, 2005; Schutz et al., 2006; Meyer \& Turner, 2002; Pekrun, 2009). Similarly, the fact that students experienced anxiety is particular important because this emotion influence students to focus towards the self than to the content of the course and the strategies taking the course (Frijda, 2005).

\subsection{Students' Cognitive Factors}

With respect to the student cognitive variables, our findings more or less supported Pekrun's $(2006,2009)$ model of student emotions, and previous researches (e.g., Frijda, 2009; Goetz et al., 2003; Kususanto et al.,2010; Lizzio et al., 2002; Pekrun \& Stephens, 2010b; Stephanou, 2006a, 2007, 2011; Van Veen \& Lasky, 2005), indicating that students' self and value beliefs positively influenced their perceptions of the teacher effectiveness, their emotional experience in lectures and the impact of rating of teacher effectiveness on emotions.

The students, in the courses taught by both groups of the teachers, had higher value beliefs than perceptions of self-ability and domain difficulty, and estimated their ability higher than the domain difficulty, showing their different role in motivating students (Eccles, 2005; Eccles, Vida, \& Barber, 2004; Pintrich, 2003; Stephanou, 2008). Also, the important role of students' course value beliefs in defying the effective teacher is in accordance to previous research (Nasser \& Fresco, 2006; Stephanou \& Kyridis, 2009). However, the ability self-perception, followed by perceived domain-difficulty and value beliefs, was the most powerful factor in separating the two groups of teachers. Ability self perception, in addition, was the most and the solo contributor in the generation of rating of teacher effectiveness and ineffectiveness, respectively. The dominant role of ability self-perception in perceiving teacher effectiveness is in accordance to previous studies, showing the appraisal of a certain learning situation is influenced by self-beliefs (Frijda, 2009; Goetz et al., 2003; Pekrun et al., 2002; Stephanou, 2011; Weiner, 2005). This specific finding might be partly explained by the educational level of the participants with respect to achievement goals and academic experience. Specifically, the studies in tertiary education are predominantly performance oriented, and high ability is considered as a prerequisite of success (Barron \& Harackiewicz, 2003; Harackiewicz et al., 2002; Pintrich, 2000; Stephanou, 2003).

In contrast to our expectations, students' perceptions of academic domain difficulty were not strongly related- and had non significant contribution into rating of both teacher effectiveness and teacher ineffectiveness. This specific finding might hind that domain difficulty was perceived by the students as a stable rather than a state factor, and, consequently, it discriminated the effective from the ineffective teachers group, but it did not further differentiate the effectiveness within each group (effective / ineffective) of teachers. Research is needed to explore this topic more.

Also, unexpectedly, students' cognitive beliefs accounted for a greater portion of the variance in the perceived teacher effectiveness than teacher ineffectiveness. This finding may lend indirect support to the notion that the students enhanced themselves by being associated with the perceived effective teachers and protected themselves by avoiding association with the perceived ineffective teachers (Stephanou, 2005, 2006a; Weiner, 2002). Further research is needed to examine the psychological processes that seem to generate perceptions of effective and ineffective teachers.

The effects of the students' ability self-perceptions and perceptions of domain- difficulty on the experienced emotions in lectures were in the main consistent with our hypotheses, the Pekrun's model and other studies (Anderman \& Wolters, 2006; Carver \& Scheier, 2000; Davidson \& Phelan, 1999; Frenzel et al., 2007; Frijda, 2005; Siemer et al., 2007), indicating that the students appraised the self- and task- related factors in classroom learning. The significant role of value beliefs in emotions is in agreement with the suggestion that emotions arise 'in response to the meaning structures of given situations' (Frijda, 1988, p. 349). However, the findings are partly in agreement with the previous research evidence that ability self perception is particularly related to self esteem- and performance- related affects, such as competence, confidence and anxiety, and pleasure, value beliefs are particularly related to interest, and perceived academic domain-difficulty is mainly associated with task- and future activity- related emotions, such as boredom, enthusiasm and confidence (Efklides, 2006b; Pekrun et al., 2002). Also, contrarily to our expectations, the students' cognitive factors more strongly influenced the majority of their experienced emotions in the lectures of the courses taught by the perceived effective teachers than ineffective teachers. As above mentioned, probably the students enhanced and protected their self-esteem. Further investigation is required for clarifying this topic.

In consistency with our hypotheses and the Pekrun's model, students' cognitive factors and perceptions of teacher effectiveness, in combination, had positive effect in the generation of the students' emotions (mainly, task- 
expectancy- and future behaviour- related) in the perceived effective teachers group. More precisely, the self (pride)goal (satisfaction)- and future behaviour (hope, confidence)- related emotions were best explained by the two sets of concepts in the perceived effective teachers group than in the perceived ineffective teachers group, whereas the reverse was the case for the context-, task- and future activity (boredom, not excitement, sadness)- related emotions. Furthermore, in accordance to other researches (see Pekrun, 2005; 2009; Stephanou, 2006a, 2007; Stephanou et al., 2011), the students' self-, academic domain difficulty and value beliefs, as a group, accounted for significant amount of variance in emotions (mainly, self-, future behaviour- and achievement related: confidence, hope, competence, excitement), even after controlling for the perceived teacher effectiveness. That means that the students, who had strong self-, academic domain and value beliefs, were more likely to consider their teacher as more favourable, and, in turn, to feel better in lectures, compared to students with low self- and value beliefs. This was mainly evident in the perceived effective teachers group (except in satisfaction, pride and encouragement), in contrast to our hypotheses.

\subsubsection{Academic Performance}

The findings regarding academic performance in the courses taught by the perceived extremely effective and ineffective teachers were in the main as expected. The three sets of concepts, namely students' competence, task and value beliefs, their perceptions of teacher effectiveness and their experienced emotions in the lectures, had positive and complementary consequences for performance in courses. However, their prevalence differed between the two groups of teachers (perceived effective / ineffective) and within each group of teachers.

More precisely, confirming previous researches (e.g., Marks, 2000; Marsh \& Dunkin, 1997; Nasser \& Fresko, 2006; Stephanou \& Kyridis, 2009; Worthington, 2002), the participants had higher academic performance in the courses taught by the perceived effective teachers than in the courses taught by the perceived ineffective teachers. Furthermore, as expected, the three set of predictors, as a group, explained a greater amount in variability in performance in the courses taught by the perceived ineffective teachers than in the courses taught by the perceived effective teachers. This specific finding probably reflects the students' tendency to search for explanation in academic unsuccessful performance (Stephanou, 2003; 2006a, b; Weiner, 2002).

Also, in line with previous researches (e.g., Hativa et al., 2001; Marks, 2000; Marsh \& Rochi, 2000 Young \& Shaw, 1999), students' perceptions of teacher ineffectiveness, and not their perceptions of teacher effectiveness, had unique effect in the generation of academic performance. This might be related to high importance of success in tertiary education, and to students' motive to protect themselves in failure (Eiszler, 2002; Forrester-Jones, 2003; Marsh \& Rochi, 2000; Stephanou, 2006a, b; Stephanou \& Kyridis, 2009). Previous studies showed that students tend to attribute their success to themselves and failure to others, particularly to instructor (Stephanou, 2003, 2005; Weiner, 2001).

Consistent with the above argument was the fact that the students' ability self-perception had unique effect in the formation of their academic performance only in the courses taught by the perceived effective teachers. Also, the greater role of ability self-perception, compared to role of both perceived academic domain difficulty and value beliefs, in performance confirmed previous studies (see Eccles \& Wigfield, 2002; Stephanou, 2006a, 2008; Stephanou et al., 2011; Weiner, 2005), and may be related to participants' beliefs that ability is required in success in tertiary education, as was mentioned above.

Also, in agreement with other studies (see Anderman \& Wolters, 2006; Pekrun et al., 2009; Pekrun et al., 2010; Pintrich, 2003; Stephanou et al., 2011), students' experienced emotions in the lectures had positive effects on performance in the courses taught by the perceived effective and ineffective teachers. More accurately, in the main in consistency with Pekrun's model, the achievement (pride, competence)- and task- and future behavior (hope, enthusiasm)- related emotions than the learning processes- related emotions influenced academic performance in the courses taught by the perceived effective teachers. In the courses taught by the perceived ineffective teachers, in addition, the goal (dissatisfaction)- related emotions contributed into performance.

Moreover, as expected, students' self- factors played significant role in the impact of their perceptions of the teacher effectiveness on the experienced emotions in the lectures, and in turn in academic performance, particularly in the courses taught by the perceived effective teachers. That means that the students, who had strong competence and value beliefs, were more likely to perceive more favourably their teacher, in turn to experience more positive emotions in the lectures, and finally, to achieve higher academic performance, relative to students with low self- and value beliefs.

\subsection{Implications of the Findings for Educational Practice and Future Research}

The findings of this study might serve to strengthen literature in teacher effectiveness in university, and reveal some 
potentially important issues. The findings of the present study also provide an insight on how perceived teacher effectiveness, cognitive factors and experienced emotions in the lectures interact in academic excellence.

Students' perceptions of teacher effectiveness, on one hand, affected their experienced emotions in the lectures and academic performance, suggesting its crucial role in facilitating students' academic development. On other hand, it was mainly affected by ability self-perceptions. Students may enhance these beliefs through opportunities for self-regulated learning, involving into meaningful task and activities, and success in challenge tasks.

The experienced emotions in lectures contributed into academic performance. It is necessary to the development of enjoyable university learning environment, and a learning environment which satisfy as many as possible aspects of students' life.

Conclusively, investigating students' perceptions of teacher effectiveness and how it interacts with their cognitive and emotion factors might provide useful information in understanding learning and achievement in tertiary education.

\section{References}

Akerlind, G. S. (2003). Growing and developing as a university teacher-variation in meaning. Studies in Higher Education, 28, 375-390

Akerlind, G. S. (2004). A new dimension to understanding university teaching. Teaching in Higher Education, 9(3), 363-375. http://dx.doi.org/10.1080/1356251042000216679

Anderman, E. M., \& Wolters, C. A. (2006). Goals, values, and affect: Influences on student motivation. In P. A. Alexander \& P. H. Winne (Eds), Handbook of Educational Psychology (pp. 369 - 389). London: Lawrence Erlbaum.

Anderman, L. H., Patrick, H., Hiruda, I. Z., \& Linnenbrink, E. A. (2002). Observing classroom goal structures to clarify and expand goal theory. In C. Midgley (Ed.), Goals, goal structures, and patterns of adaptive learning (pp. 243 -278). Mahwah, NJ: Lawrence Erlbaum.

Aquario, D. (2009). The active participation of students in teaching evaluation processes within universities. Vienna: In-tech.

Astleitner, H. (2000). Designing emotionally sound instruction: the FEASP-approach. Instructional Science, 28, 169-198. http://dx.doi.org/10.1023/A:1003893915778

Averill, J. (1997). The emotions: an integrative approach. In R. Hogan, J. Johnson, J. and S. Briggs (Eds), Handbook of Personality Psychology (pp. 513-541). New York: Academic Press.

Barron, K. E., \& Harackiewicz, J. M. (2003). Achievement goals and optimal motivation: Testing multiple goal models. Journal of Personality and Social Psychology, 80(5), 706 - 722. http://dx.doi.org/10.1037/0022-3514.80.5.706

Beane, J. (1999). Sorting out the self-esteem controversy. Educational Leadership, 49(1) Sept.25 -30.

Biggs, J. (1993). What do inventories of students' learning process really measure? A theoretical review and $\begin{array}{llllll}\text { clarification. British Journal of } & \text { Educational }\end{array}$ http://dx.doi.org/10.1111/j.2044-8279.1993.tb01038.x

Biggs, J. (1999). What the student does: Teaching for enhanced learning. Higher Education Research and Development, 181, 57-75. http://dx.doi.org/10.1080/0729436990180105

Biggs, J. (2003). Teaching for quality learning at university (2nd ed.). Buckingham: SRHE.

Boekaerts, M., Pintrich, P., \& Zeidner, M. (2000). Handbook of self-regulation. London: Academic.

Brok, P. den (2001). Teaching and students outcomes: A study on teachers' thoughts and actions from an interpersonal and a learning activities perspective. Utrecht: W.C.C.

Bruinsma, M. (2004). Motivation, cognitive processing and achievement in higher education. Learning and Instruction, 14, 549 - 568. http://dx.doi.org/10.1016/j.learninstruc.2004.09.001

Carnell, E. (2007). Conceptions of effective teaching in higher education: Extending the boundaries. Teaching in Higher Education, 12(1), 25 - 40. http://dx.doi.org/10.1080/13562510601102081

Carver, C. S., \& Scheier, M. E. (2000). Scaling back goals and readibration of the affect system are processes in normal adaptive self-regulation: understanding 'response shift' phenomena. Social Science and Medicine, 50, 1715-1722. http://dx.doi.org/10.1016/S0277-9536(99)00412-8

Chalmers, D, \& Fuller, R. (1996). Teaching for learning at university. London: Kogan Page 
Clore, G. L., \& Huntsinger, J. R. (2009). A reply to commentaries: How the object of affect guides its impact. Emotion Review, 1, 58-59. http://dx.doi.org/10.1177/1754073908097185

Cohen, J. (1992). A power primer. Psychological Bulletin, 112, 155-159. http://dx.doi.org/10.1037/0033-2909.112.1.155

Cuthbert, P. F. (2007). The student learning process: Learning styles or learning approaches? Teaching in Higher Education, 10(2), 235-249. http://dx.doi.org/10.1080/1356251042000337972

Davidson, A. L., \& Phelan, P. (1999). Students' multiple worlds: An anthropological approach to understanding students' engagement with school. In Urdan, T. C. (Ed.), Advances in motivation of context (Vol. 11, pp. 233-273). Stamford, CT: JAI.

Davis, H. A. (2003). Conceptualizing the role and influence of student-teacher relationship on childern's social and cognitive development. Educational Psychologist, 38, 207-234. http://dx.doi.org/10.1207/S15326985EP3804_2

De la Fuente, J. (2004). Recent perspectives in the study of motivation: Goal Orientation Theory. Electronic Journal of Research in Educational Psychology, 2(1), 35-62.

Diener, E. (2000). Subjective well-being. The science of happiness and a proposal for national index. American Psychologist, 55(1), 34 - 43. http://dx.doi.org/10.1037/0003-066X.55.1.34

Dina, F., \& Efklides, A. (2009). Metacognitive experiences as the link between situational characteristics, motivation, and affect in self-regulated learning. In M. Wosnitza, S. A. Karabenick, A. Efklides, \& P. Nenniger (Eds.), Contemporary motivation research: From global to local perspectives (pp. 117-146). Cambridge: Hogrefe \& Huber.

Do, S. L., \& Schallert, D. L. (2004). Emotions and classroom talk: Toward a model of the role of affect in students' experiences of classroom discussions. Journal of Educational Psychology, 96(4), 619-634. http://dx.doi.org/10.1037/0022-0663.96.4.619

Dunkin, M. J., \& Precians, R. P. (1992). Award-winning university teachers' conceptions of teaching. Higher Education 24, pp. 483-502. http://dx.doi.org/10.1007/BF00137244

Eccles, J. S. (2005). Studying the development of learning and task motivation. Learning and Instruction, 15, 161-171. http://dx.doi.org/10.1016/j.learninstruc.2005.04.012

Eccles, J. S., \& Wigfield, A. (2002). Motivational beliefs, values and goals. Annual Review of Psychology, 53, 109-132. http://dx.doi.org/10.1146/annurev.psych.53.100901.135153

Eccles, J. S., Barber, B. L., Updegraff, K., \& O’ Brien, K. (1998). An expectancy-value model of achievement choices: The role of ability self-concepts, perceived task utility and interest in predicting activity choice and course enrollment. In L. Hoffman, A. Krapp, K. A. Renninger, \& J. Baumert (Eds.), Interest and learning; Proceedings of the Seeon Conference on Interest and Gender (pp. 267-280). Kiel, Germany: IPN.

Eccles, J. S., Vida, M. N., \& Barber, B. L. (2004). The relation of early adolescents' college plans, and both academic ability and task value beliefs to subsequent college enrolment. Journal of Early Adolescence, 24, 63-77. http://dx.doi.org/10.1177/0272431603260919

Efklides, A. (2006a). Metacognition, affect, and conceptual difficulty. In J. Meyer \& R. Land (Eds.), Overcoming barriers to student understanding: Threshold concepts and troublesome knowledge (pp. 48-69). London: Routledge-Falmer.

Efklides, A. (2006b). Metacognition and affect: What can metacognitive experiences tell us about the learn-ing process? Educational Research Review, 1, 3-14. http://dx.doi.org/10.1016/j.edurev.2005.11.001

Efklides, A. (2009). The new look in metacognition: From individual to social, from cognitive to affective. In C. B. Larson (Ed.), Metacognition: New research developments (pp. 137-151). New York: Nova Science.

Efklides, A., \& Petkaki, C. (2005). Effects of mood on students' metacognitive experiences, Learning and Instruction, 15, 415-431.

Efklides, A., \& Volet, S. (Eds.). (2005). Feelings and emotions in the learning process. Learning and Instruction, 15(5) [whole issue]. http://dx.doi.org/10.1016/j.learninstruc.2005.07.010

Eiszler, C. F. (2002). College student evaluations of teaching and grade inflation. Research in Higher Education, 43(4), 483-501. http://dx.doi.org/10.1023/A:1015579817194

Forrester-Jones, R. (2003). Students' perceptions of teaching: The research is alive and well. Assessment and Evaluation in Higher Education, 28(1), 59-69. http://dx.doi.org/10.1080/02602930301688 
Fredrickson, B. I. (2001). The role of positive emotions in positive psychology: The broaden-and-build theory of positive emotions. American Psychologist, 56, 218-226. http://dx.doi.org/10.1037/0003-066X.56.3.218

Frenzel, A. C., Goetz, T., Lüdtke, O., Pekrun, R., \& Sutton, R. (2009). Emotional transmission in the classroom: Exploring the relationship between teacher and student enjoyment. Journal of Educational Psychology, 101, 705-716. http://dx.doi.org/10.1037/a0014695

Frenzel, A. C., Pekrun, R., \& Goetz, T. (2007). Perceived learning environments and students' emotional experiences: A multilevel analysis of mathematics classrooms. Learning and Instruction, 17, 478-493. http://dx.doi.org/10.1016/j.learninstruc.2007.09.001

Frijda, N. H. (1988). The laws of emotion. American Psychologist, 43(5), 349-358. http://dx.doi.org/10.1037/0003-066X.43.5.349

Frijda, N. H. (2000). The psychologists' point ofview. In M. Lewis, \& J. M. Haviland-Jones (Eds.), Handbook of emotions (2nd ed) (pp. 59-74). New York/London: The Guilford Press.

Frijda, N. H. (2005). Emotion experience. Cognition \& Emotion, 19, 473-498. http://dx.doi.org/10.1080/02699930441000346

Frijda, N. H. (2007). The laws of emotion. Mahwah: Erlbaum.

Frijda, N. H. (2009). Emotion experience and its varieties. Emotion Review, 1, 261-271. http://dx.doi.org/10.1177/1754073909103595

Furrer, C., \& Skinner, E. (2003). Sense of relatedness as a factor in children's academic engagement and performance. Journal of Educational Psychology, 95(1), 148-162. http://dx.doi.org/10.1037/0022-0663.95.1.148

Ghedin, E., \& Aquario, D. (2008). Moving towards multidimensional evaluation of teaching in higher education: A study across four faculties. Higher Education, 56, 583-597. http://dx.doi.org/10.1007/s10734-008-9112-x

Glaser-Zikuda, M., \& Mayring, Ph. (2003). A qualitative oriented approach to learning emotions at school. In Ph. Mayring, \& Ch. V. Rhoneck (Eds.), Learning emotions. The influence of affective factors on classroom learning (pp. 103 - 126). New York: Lang.

Glaser-Zikuda, M., Fub, S., Laukenmann, M., Metz, K., \& Randler, C. (2005). Promoting students' emotions and achievement- instructional design and evaluation of the ECOLE-approach. Learning and Instruction, 15, 481 - 495. http://dx.doi.org/10.1016/j.learninstruc.2005.07.013

Goetz, T., Frenzel, A. C., Hall, N. C., \& Pekrun, R. (2008). Antecedents of academic emotions: Testing the internal/external frame of reference model for academic enjoyment. Contemporary Educational Psychology, 33, 9-33. http://dx.doi.org/10.1016/j.cedpsych.2006.12.002

Goetz, T., Zirngibl, A., Pekrun, R, \& Hall, N. (2003). Emotions, learning and achievement from an educational-psychological perspective. In P. Mayring \& C. V. Rhoeneck (Eds.), Learning and emotions: The influence of affective factors on classroom learning (pp. 9 - 28). Frankfurt am Main: Peter Lang.

Greenwald, A., \& Gillmore, G. (1997). Grading leniency is a removable contaminant of student ratings. American Psychologist, 52(11), 1209 - 1217. http://dx.doi.org/10.1037/0003-066X.52.11.1209

Harackiewicz, J. M., Barron, K. E., Tauer, J. M., \& Elliot, A. J. (2002). Predicting success in college: A longitudinal study of achievement goals and ability measures as predictors of interest and performance from freshman year through graduation. Journal of Educational Psychology, 94(3), 562 - 575. http://dx.doi.org/10.1037/0022-0663.94.3.562

Hargreaves, A. (2001). The emotional geographies of teaching. Teachers' College Record, 103(6), 1056-1080. http://dx.doi.org/10.1111/0161-4681.00142

Hascher, T. (2003). Well-being in school - why students need social support. In Ph. Mayring, \& Ch. V. Rhoneck (Eds.), Learning emotions. The influence of affective factors on classroom learning (pp. 127 - 142). New York : Lang.

Hativa, N., Barak, R., \& Simhi, E. (2001). Exemplary university teachers: Knowledge and beliefs regarding effective teaching dimensions and strategies. The Journal of Higher Education, 72(6), 699 - 727. http://dx.doi.org/10.2307/2672900

Jarvenoja, H., \& Jarvela, S. (2005). How students describe the sources of their emotional and motivational experiences during the learning process: A qualitative approach. Learning and Instruction, 15, 465 - 480. http://dx.doi.org/10.1016/j.learninstruc.2005.07.012 
Kember, D., \& Wong, A. (2000). Implications for evaluation from a study of students' perceptions of good and poor teaching. Higher Education, 40(1), 69-97. http://dx.doi.org/10.1023/A:1004068500314

Kim, G., Walden, T., Harris, V., Karrass, J., \& Catron, T. (2007). Positive emotion, negative emotion, and emotion control in the externalizing problems of school-aged children. Child Psychiatry of Human Development, 37, 221-239. http://dx.doi.org/10.1007/s10578-006-0031-8

Kuhbandner, C., Hanslmayr, S., Maier, M. A., Pekrun, R., Spitzer, B. J., Pastötter, B., \& Bäuml, K.-H. (2009). Effects of mood on the speed of conscious perception: Behavioral and electrophysiological evidence. Social Cognitive and Affective Neuroscience, 4, 286-293. http://dx.doi.org/10.1093/scan/nsp010

Kususanto, P., Ismail, H. N., \& Jamil, H. (2010). Students' self-esteem and their perceptions of teacher behaviour: A study of between-glass ability grouping. Electronic Journal of Research in Educational Psychology, 8(2), 707-724.

Kuyper, H., van der Werf, M., \& Lubbers, M. (2000). Motivation, Meta-Cognition and Self-Regulation as Predictors of Long Term Educational Attainment. Educational Research and Evaluation, 6(3), 181-205. http://dx.doi.org/10.1076/1380-3611(200009)6:3;1-A;FT181

Linnenbrink, E. A., \& Pintrich, P. A. (2002). Achievement goal theory and affect: An asymmetrical bidirectional model. Educational Psychologist, 37, 69-78. http://dx.doi.org/10.1207/S15326985EP3702_2

Lizzio, A., Wilson, K., \& Simons, R. (2002). University students' perceptions of the learning environment and academic outcomes: Implications for theory and practice. Studies in Higher Education, 27(1), 27-52. http://dx.doi.org/10.1080/03075070120099359

Marks, R. B. (2000). Determinants of student evaluations of global measures of instructor and course value. Journal of Marketing Education, 22(2), 108-119. http://dx.doi.org/10.1177/0273475300222005

Marsh, H. W., \& Dunkin, M. J. (1997). Students' evaluation of university teaching: multidimensional perspective. In R. P. Perry \& J. C. Smart (Eds.) Effective teaching in higher education (pp.241 - 320). New York: Agathon.

Marsh, H. W., \& Hatie, J. (2002). The relation between research productivity and teaching effectiveness. Complementary, antagonistic, or independent constructs? The Journal of Higher Education, 73(5), 603-641. http://dx.doi.org/10.1353/jhe.2002.0047

Marsh, H. W., \& Rochi, L. A. (2000). Effects of grading leniency and low workload on students' evaluations of popular myth, bias, validity, or innocent bystanders? Journal of Educational Psychology, 92(1), 202-228. http://dx.doi.org/10.1037/0022-0663.92.1.202

McLean, M., \& Blackwell, R. (1997). Opportunity knocks? Professionalism and excellence in university teaching. Teachers \& Teaching: Theory and Practice, 3(1), pp. 85-99.

Meyer, D. K. (2009). Entering the Emotional Practices of Teaching. In P. A. Schutz \& M. Zembylas (Eds.), Advances in Teacher Emotion Research (pp., 73-91). NY: Springer.

Meyer, D. K., \& Turner, J. C. (2002). Discovering emotion in classroom motivation research. Educational Psychologist, 37(2), 107 -114. http://dx.doi.org/10.1207/S15326985EP3702_5

Murray, H. G. (2001). Higher education: Handbook of theory and research. New York: Agathon.

Murray, H.G. (1997). Does evaluation of teaching lead to improvement of teaching? International Journal for Academic Development, 2(1), 8 - 23. http://dx.doi.org/10.1080/1360144970020102

Nasser, F., \& Fresko, B. (2006). Predicting student ratings: The relationship between actual student ratings and instructors' predictions. Assessment \& Evaluation in Higher Education, 31, 1-18. http://dx.doi.org/10.1080/02602930500262338

Nias, J. (1996). Thinking about feeling: The emotions in teaching. Cambridge Journal of Education, 26(3), 293-306. http://dx.doi.org/10.1080/0305764960260301

Oosterheert, I. E., \& Vermunt, J. D. (2001). Individual differences in learning to teach: Relating cognition, regulation and affect. Learning and Instruction, 11(2), 133 -156. http://dx.doi.org/10.1016/S0959-4752(00)00019-0

Park, L.E., Crocker, J., \& Kiefer, A.K. (2007). Contingencies of self-worth, academic failure, and goal pursuit. Personality and Social Psychology Bulletin, 33(11), 1503 - 1517. http://dx.doi.org/10.1177/0146167207305538

Pekrun, R. (1992). The impact of emotions on learning and achievement: Towards a theory of cognitive/motivational mediators. Applied Psychology: An International Review, 41, 359-376. http://dx.doi.org/10.1111/j.1464-0597.1992.tb00712.x 
Pekrun, R. (2000). A social-cognitive, control - value theory of achievement emotions. In J. Heckhausen (Ed.), Motivational psychology of human development (pp. 143 - 163). Oxford: Elsevier. http://dx.doi.org/10.1016/S0166-4115(00)80010-2

Pekrun, R. (2005). Progress and open problems in educational emotion research. Learning and Instruction, 15, 497-506. http://dx.doi.org/10.1016/j.learninstruc.2005.07.014

Pekrun, R. (2006). The control-value theory of achievement emotions: Assumptions, corollaries, and implications for educational research and practice. Educational Psychology Review, 18, 315-341. http://dx.doi.org/10.1007/s10648-006-9029-9

Pekrun, R. (2009). Emotions at school. In K. R. Wentzel \& A. Wigfield (Eds.), Handbook of motivation in school (pp. 575 - 605). New York: Routledge Taylor.

Pekrun, R., \& Schutz, P. A. (2007). Where do we go from here? Implications and future directions for inquiry on emotions in education. In P. A. Schutz \& R. Pekrun (Eds.), Emotion in education (pp. 313-331). San Diego, CA: Academic Press.

Pekrun, R., \& Stephens, E. J. (2009). Goals, emotions, and emotion regulation: Perspectives of the control-value theory of achievement emotions. Human Development, 52, 357-365. http://dx.doi.org/10.1159/000242349

Pekrun, R., \& Stephens, E. J. (2010a). Achievement emotions: A control-value approach. Social and Personality Psychology Compass, 4, 238-255. http://dx.doi.org/10.1111/j.1751-9004.2010.00259.x

Pekrun, R., \& Stephens, E. J. (2010b). Achievement emotions in higher education. In J. C. Smart (Ed.), Higher education: Handbook of theory and research (vol. 25, pp. 257). New York: Springer. http://dx.doi.org/10.1007/978-90-481-8598-6_7

Pekrun, R., Elliot, A. J., \& Maier, M. A. (2009). Achievement goals and achievement emotions: Testing a model of their joint relations with academic performance. Journal of Educational Psychology, 101, 115-135. http://dx.doi.org/10.1037/a0013383

Pekrun, R., Frenzel, A., Goetz, T., \& Perry, R. P. (2007). The control-value theory of achievement emotions: An integrative approach to emotions in education. In P. A. Schutz \& R. Pekrun (Eds.), Emotion in education (pp. 13-36). San Diego, CA: Academic Press.

Pekrun, R., Goetz, T., Daniels, L. M., Stupnisky, R. H., \& Perry, R. P. (2010). Boredom in achievement settings: Control-value antecedents and performance outcomes of a neglected emotion. Journal of Educational Psychology, 102, 531-549. http://dx.doi.org/10.1037/a0019243

Pekrun, R., Goetz, T., Titz, W., \& Perry, R. P. (2002). Academic emotions in students' self-regulated learning and achievement: A program of qualitative and quantitative research. Educational Psychologist, 82(1), 33- 40.

Perry, N. E., Turner, J. C., \& Meyer, D. K. (2006). Classroom as contexts for motivating learning. In P. A. Alexander \& P. H. Winne (Eds), Handbook of Educational Psychology (pp. 327 - 348). London: Lawrence Erlbaum.

Pickering, A. M. (2006). Learning about university teaching: Reflections on a research study investigating influences for change. Teaching in Higher Education, 11(3), 319-335. http://dx.doi.org/10.1080/13562510600680756

Pintrich, P. R. (2000). An achievement goal theory perspective on issues in motivation terminology, theory and research. Contemporary Educational Psychology, 25, 92 - 104. http://dx.doi.org/10.1006/ceps.1999.1017

Pintrich, P. R. (2003). A motivational science perspective on the role of student motivation in learning and teaching contexts. Journal of Educational Psychology, 95(4), 667-686. http://dx.doi.org/10.1037/0022-0663.95.4.667

Pintrich, P. R., \& Schunk, D. (2002). Motivation in education: Theory, research, and applications ( $2^{\text {nd }}$ ed.). Upper Saddle River, NJ: Prentice Hall.

Radmacher, S. A., \& Martin, D. J. (2001). Identifying significant predictors of student evaluations of faculty through hierarchical regression analysis. The Journal of Psychology, 135(3), 259-268. http://dx.doi.org/10.1080/00223980109603696

Rodger, S., Murray, H. G., \& Cummings, A. L. (2007). Effects of teacher clarity and student anxiety on student outcomes. Teaching in Higher Education, 12(1), 91 - 104. http://dx.doi.org/10.1080/13562510601102255

Rosiek, J., \& Beghetto, R. A. (2009). Emotional scaffolding: The emotional and imaginative dimensions of teaching and learning. In P. A., Schutz \& M. Zembylas, M. (Eds.), Advances in Teacher Emotion Research: The impact on teachers' lives (pp. 175 -194). London: Springer Science and Business Media. 
Sander, P. (2005). Researching our students for more effective university teaching. Electronic Journal of Research in Educational Psychology, 3 (1), 113-130.

Schutz, P. A. Hong, J. Y., Cross, D. I., \& Osbon, J. N. (2006). Reflections on investigating emotions among educational contexts. Educational Psychology Review, 18, 343 -360. http://dx.doi.org/10.1007/s10648-006-9030-3

Schutz, P. A., \& Zembylas, M. (2009). Introduction to Advances in Teacher Emotion Research: The Impact on Teachers' Lives. In P. A. Schutz \& M. Zembylas (Eds.), Advances in Teacher Emotion Research (pp., 3-11). NY: Springer.

Schutz, P. A., \& DeCuir, J. T. (2002). Inquiry on emotions in education. Educational Psychologist, 37(2), 125 - 134. http://dx.doi.org/10.1207/S15326985EP3702_7

Schutz, P. A., \& Lenehart, S. J. (2002). Emotions in education. Educational Psychologist, 37(2), 67-78. http://dx.doi.org/10.1207/S15326985EP3702_1

Siemer, M., Mauss I., \& Gross, J. (2007). Same situation-Different emotions: How appraisals shape our emotions. Emotion, 7, 592-600. http://dx.doi.org/10.1037/1528-3542.7.3.592

Stephanou, G, \& Tatsis, K. (2008). Effects of Value Beliefs, Academic self-esteem, and Overgeneralization of Failure Experience on the Generation of Emotions and Attributions for Academic Performance. International Journal of Learning, 15(11), 201- 220.

Stephanou, G. (2003). The effect of performance expectations on the formation of both attributions and emotions for academic performance in real achievement situations in tertiary education [in Greek]. Psychology: The Journal of the Hellenic Psychological Society, 10(1), 160-179.

Stephanou, G. (2004a). Ability self-perception, perceived task difficulty, performance expectations, and task value in language and mathematics: Their relationship to academic performance and educational choice [in Greek]. In M. Dikaiou, P. Roussi, \& D. Cristidis (Eds.), Scientific Annals of the School of Psychology (Vol. VI, pp. 65-93). Thessaloniki, Greece: Aristotle University of Thessaloniki/Art of Text.

Stephanou, G. (2004b). Effects of ability self-perception, perceived task-difficulty, performance expectations and importance of performance on performance and attributions in specific academic domains. In J. Baumert, H. W. Marsh, U. Trautwein, \& G. E. Richards (Eds), Proceedings of the $3^{\text {rd }}$ International SELF Research Conference: Self-Concept, Motivation and Identity (CD form). Berlin, Germany: Max Planck Institute for Human Development. [Online] Available: http://www.self.ox.ac.uk

Stephanou, G. (2005). Academic performance and interpersonal relationships [in Greek]. In F. Vlachos, F. Bonoti, P. Metallidou, I. Dermitzaki, \& A. Efklides (Eds.), Human behavior and learning. Scientific Annals of the Psychological Society of Northern Greece (Vol. 3, pp. 201-228). Athens: Ellinika Grammata

Stephanou, G. (2006a). Effects of cognitive factors and teacher effectiveness on students' academic emotions and performance. In R. G. Graven, J. Eccles, \& M. Tr. Ha (Eds), Proceedings of the 4th SELF Research Conference: Self-concept, Motivation, Social and Personal Identity for the 21st Century (CD form). Sydney, Australia: SELF Research Center, University of Western Sydney. [Online] Available: http//self.uws.edu.au

Stephanou, G. (2006b). Students' learning style, preferences for teacher characteristics, perceived teacher effectiveness and academic performance. In L. Lassen, L. Bostrom, \& C. Evans, (Eds.), Proceeding of the 11th Annual Conference of the European Learning Styles Information Network: Enabling Lifelong learning in Education, Training and Development (CD Form). Oslo, Norway: University of Oslo.

Stephanou, G. (2007). Effects of cognitive and perceived teacher- related factors on student emotions in physical education. In Y. Theodorakis, M. Goudas, \& A. Papaioannou (Eds.), Proceedings of the $12^{\text {th }}$ European Congress of Sport Psychology. Sport and Exercise Psychology. Bridges between disciplines and culture, 242 - 247. Greece: University of Thessaly \& European Federation of Sport Psychology.

Stephanou, G. (2008). Students' value beliefs, performance expectations, and school performance: The effect of school subject and gender. Hellenic Journal of Psychology: The Journal of the Psychological Society of Northern Greece, 5, 231-257.

Stephanou, G. (2011). Students' classroom emotions: Cognitive antecedents and school performance. Electronic Journal of Research in Educational Psychology, 9 (1), 1-42.

Stephanou, G., \& Kyridis, A. (2008, August). Interrelations of cognition, emotions and perceived teacher effectiveness in student academic performance in teacher education. Paper presented at the International Conference on Educational Effectiveness (EARLI SIG18). Theoretical and Methodological Challenges for Research. Frankfurt, 


\section{Germany.}

Stephanou, G., \& Kyridis, A. (2009). Students' perceptions of teacher effectiveness, and academic performance in Greek tertiary education [in Greek]. In A. Brouzos, P. Misailidi, \& A. Efklides (Eds), Studies in Psychological Assessment. Scientific Annals of the Psychological Society of Northern Greece (Vol. 7, pp. 181-215). Athens: Ellinika Grammata

Stephanou, G., Kariotoglou, P., \& Dinas, K. (2011). University students' emotions in lectures: The effect of competence beliefs, value beliefs and perceived task-difficulty, and the impact on academic performance. International Journal of Learning. 18(1), 45-72.

Terenzini, P. T. (1998). Research and practice in undergraduate education. Paper presented at Kansas State University - Manhattan, KS.

Trope, Y., Hassin, R., \& Gervey, B. (2001). Overcoming defensive feedback seeking. In A. Efklides, J. Kuhl, \& R. Sorrentino (Eds), Trends and prospects in motivation research (pp. 201-220). Dordrecht, the Netherlands: Kluwer.

Turner, J. C., \& Meyer, D. K., (2000). Studing and understanding the instructional contexts of classroom: using our past to figure our future. Educational Psychologist, 35, 69-85. http://dx.doi.org/10.1207/S15326985EP3502_2

Turner, J. C., \& Schallert, D. L. (2001). Expectancy-value relationships of shame reactions and shame resiliency. Journal of Educational Psychology, 93, 320 - 329. http://dx.doi.org/10.1037/0022-0663.93.2.320

Turner, J. C., Thorpe, P. K., \& Meyer, D. K. (1998). Stedents' reports on motivation and negative affect: a theoretical and empirical analysis. Journal of Educational Psychology, 90, 758-791. http://dx.doi.org/10.1037/0022-0663.90.4.758

Van Veen, K., \& Lasky, S. (2005). Emotions as a lens to explore teacher identity and change: Different theoretical approaches. Teaching and Teacher Education, 21, 895-898. http://dx.doi.org/10.1016/j.tate.2005.06.002

Vauras, M., Salonen, Lehtinen, P., \& Kinnunen, R. (2009). Motivation in school from contextual and longitudinal perspectives. In M. Wosnitza, S. A. Karabenick, A. Efklides \& P. Nenniger (Eds.), Contemporary motivation research: From global to local perspectives (pp. 1- 23). Cambridge: Hogrefe \& Huber.

Vauras, M., Salonen, P., \& Kinnunen, R. (2008). Influences of group processes and interpersonal regulation on motivation, affect and achievement. In M. Maehr, S. Karabenick \& T. Urdan (Eds.), Social Psychological Perspectives. Advances in Motivation and Achievement, Vol. 15, pp. 275-314. New York: Emerald Group.

Vermetten, Y. J., Vermunt, J. D., \& Lodewijks, H. G. (2002). Powerful learning environments? How university students differ in their response to instructional measures. Learning and Instruction, 12, 263- 284. http://dx.doi.org/10.1016/S0959-4752(01)00013-5

Weiner, B. (1992). Human motivation: Metaphors, theories and research. London: Sage.

Weiner, B. (2001). Intrapersonal and interpersonal theories of motivation from an attribution perspective. In S. Farideh \& C. Chi-yue (Eds.), Student motivation: The culture and context of learning. Plenum series on human exceptionality (pp. 17 - 30). Dordrecht, The Netherlands: Kluwer Academic Publishers.

Weiner, B. (2002). Social emotions and personality inferences: A scaffold for a new direction in the study of achievement motivation. Paper at the 8th International Conference on motivation: Workshop on Achievement and Task Motivation \& Motivation and Emotion, Moskow, Russia.

Weiner, B. (2005). Motivation from an attribution perspective and the social psychology of perceived competence. In Elliot, A. J., \& Dweck, C. S. (Eds.), Handbook of Competence and Motivation (pp. 73-84). New York: Guilford.

Wentzel, K. R. (1998). Student motivation in middle school: The role of perceived pedagogical caring. Journal of Educational Psychology, 82, 616- 622.

Wentzel, K. R. (2002). Are effective teachers like good parents? Teaching styles and students' adjustment in early adolescence. Child Development, 73, 287 - 301. http://dx.doi.org/10.1111/1467-8624.00406

Wigfield, A., \& Eccles, J. (2000). Expectancy value theory of achievement motivation. Contemporary Educational Psychology, 25, 68-81. http://dx.doi.org/10.1006/ceps.1999.1015

Worthington, A. C. (2002). The impact of student perceptions and characteristics on teaching evaluations: A case study in finance education. Assessment \& Evaluation in Higher Education, 27(1), 49-64. http://dx.doi.org/10.1080/02602930120105054

Wosnitza, M., \& Volet, S. (2005). Origin, direction and impact of emotions in social online learning. Learning and Instruction, 15, 449-464. http://dx.doi.org/10.1016/j.learninstruc.2005.07.009 
Young, S., \& Shaw, D. G. (1999). Profiles of effective college and university teachers. The Journal of Higher Education, 70(6), 670-680. http://dx.doi.org/10.2307/2649170

Zabaleta, F. (2007). The use and misuse of student evaluations of teaching. Teaching in Higher Education, 12(1), 55 - 76. http://dx.doi.org/10.1080/13562510601102131

Zeidner, M. (1998). Test anxiety: The state of the art. New York: Plenum.

Zeidner, M. (2007). Test anxiety in educational contexts: What I have learned so far. In P. A. Schutz \& R. Pekrun (Eds.), Emotion in education (pp. 165-. 184). Boston: Elsevier.

Zimmerman, B. J., \& Schunk, D. H. (2001). Self-regulated learning and academic achievement. Theoretical perspectives. Mahwah, NJ: Lawrence Erlbauum.

\section{Notes}

Note 1. According to Cohen (1992), small, medium, and large effect sizes are $.20, .50$, and .80 , respectively.

Table 1. Discriminant analysis for the students' experienced emotions in lectures of the courses taught by the perceived effective teachers and ineffective teachers

\begin{tabular}{|c|c|c|c|c|c|c|c|}
\hline & \multicolumn{2}{|c|}{ Effective teachers } & \multicolumn{2}{|c|}{ Ineffective teachers } & \multirow[b]{2}{*}{$\begin{array}{l}\text { Discrimina- } \\
\text { ting power }\end{array}$} & \multirow[b]{2}{*}{ Cohen's d } & \multirow[b]{2}{*}{$\mathrm{F}$} \\
\hline & Mean & $\mathrm{SD}$ & Mean & $\mathrm{SD}$ & & & \\
\hline Happiness & 6.04 & .95 & 3.94 & 1.33 & -- & 1.39 & 712.38 \\
\hline Satisfaction & 6.24 & .85 & 3.31 & 1.49 & -- & 1.55 & 1323.45 \\
\hline Pleasure & 6.49 & .80 & 3.50 & 1.48 & .76 & 1.59 & 1883.70 \\
\hline Pride & 5.68 & 1.03 & 4.04 & 1.41 & .38 & 1.10 & 620.00 \\
\hline Encouragement & 6.38 & .88 & 3.70 & 1.63 & -- & 1.44 & 1190.30 \\
\hline Confidence & 6.31 & .93 & 3.65 & 1.77 & .54 & 1.37 & 1272.32 \\
\hline Not anger-anger & 6.41 & .93 & 4.40 & 1.59 & -- & 1.21 & 460.90 \\
\hline Not boredom-boredom & 6.47 & .71 & 3.28 & 1.81 & .67 & 1.53 & 1078.00 \\
\hline Cheerfulness & 6.23 & .90 & 4.21 & 1.31 & -- & 1.33 & 539.17 \\
\hline Interest & 6.27 & .84 & 3.27 & 1.79 & .62 & 1.46 & 840.90 \\
\hline Not irritated-irritated & 6.43 & .86 & 3.87 & 1.50 & .61 & 1.45 & 1183.30 \\
\hline Hope & 6.37 & .77 & 3.66 & 1.75 & .58 & 1.40 & 908.65 \\
\hline Competence & 5.92 & 1.38 & 3.95 & 1.62 & -- & 1.09 & 400.25 \\
\hline Calmness & 6.27 & .83 & 4.23 & 1.24 & .55 & 1.39 & 1047.30 \\
\hline Anxiety & 5.94 & 1.39 & 3.47 & 1.74 & .45 & 1.23 & 430.25 \\
\hline Enthusiasm & 6.46 & .78 & 3.90 & 1.49 & .62 & 1.47 & 1120.00 \\
\hline Excitement & 6.47 & .74 & 3.14 & 1.69 & .73 & 1.57 & 1284.80 \\
\hline
\end{tabular}

Note: All F(1, 819)- values are significant at the .01 level of significance; $--=$ not significant contribution in discriminating the two groups; the nature of the emotions are positive and negative in the effective teachers group and ineffective teachers group, respectively. 
Table 2. Correlations among students' rating of teacher effectiveness, their cognitive factors (ability-self perceptions, perceptions of domain-difficulty, value beliefs), their academic performance and their experienced emotions in lectures of the courses taught by the perceived effective and ineffective teachers

\begin{tabular}{|c|c|c|c|c|c|c|c|c|c|c|}
\hline & Perceived eff & tive teachers & & & & Perceived ine & ective teachers & & & \\
\hline$(\mathrm{N}=410)$ & $\begin{array}{l}\text { Teacher } \\
\text { effectiveness }\end{array}$ & $\begin{array}{l}\text { Ability } \\
\text { self-perceptions }\end{array}$ & $\begin{array}{l}\text { Domain- } \\
\text { difficulty }\end{array}$ & $\begin{array}{l}\text { Value } \\
\text { beliefs }\end{array}$ & $\begin{array}{l}\text { Academic } \\
\text { performance }\end{array}$ & $\begin{array}{l}\text { Teacher } \\
\text { effectiveness }\end{array}$ & $\begin{array}{l}\text { Ability } \\
\text { self-perceptions }\end{array}$ & $\begin{array}{l}\text { Domain- } \\
\text { difficulty }\end{array}$ & $\begin{array}{l}\text { Value } \\
\text { beliefs }\end{array}$ & $\begin{array}{l}\text { Academic } \\
\text { performance }\end{array}$ \\
\hline Happiness & .35 & .34 & .55 & .56 & .36 & -- & .28 & .37 & .25 & .35 \\
\hline Satisfaction & .25 & .39 & .22 & .46 & .26 & .42 & .36 & .46 & .33 & .64 \\
\hline Pleasure & .28 & .37 & .50 & .40 & .25 & .37 & .33 & .34 & .31 & .56 \\
\hline Pride & .47 & .57 & .34 & .62 & .43 & .43 & .33 & .40 & .39 & .40 \\
\hline Encouragement & .30 & .26 & .36 & .37 & .22 & .41 & .37 & .33 & .39 & .44 \\
\hline Confidence & .28 & .48 & .17 & .61 & .37 & .52 & .30 & .39 & .32 & .51 \\
\hline $\begin{array}{l}\text { Not angry- } \\
\text { angry }\end{array}$ & -- & .37 & .19 & .44 & .31 & .20 & .17 & .36 & -- & .33 \\
\hline $\begin{array}{l}\text { Not boredom- } \\
\text { boredom }\end{array}$ & .28 & .41 & .52 & .62 & .32 & .54 & .35 & .33 & .23 & .52 \\
\hline Cheerfulness & .31 & .18 & .32 & .43 & .20 & .20 & .25 & .31 & .21 & .27 \\
\hline Interest & .21 & .41 & .57 & .44 & .22 & .47 & .39 & .35 & .36 & .42 \\
\hline $\begin{array}{l}\text { Not irritated- } \\
\text { irritated }\end{array}$ & .34 & .53 & .22 & .62 & .34 & .22 & .18 & .39 & -- & .35 \\
\hline Hope & .36 & .42 & .39 & .65 & .29 & .54 & .45 & .40 & .38 & .55 \\
\hline Competence & .35 & .49 & .18 & .66 & .36 & .22 & .32 & .32 & .54 & .33 \\
\hline Calmness & -- & .26 & .30 & .46 & .22 & .25 & -- & -- & .20 & .26 \\
\hline Anxiety & .25 & .35 & .56 & .36 & .18 & -- & .18 & .32 & .19 & .28 \\
\hline Enthusiasm & .38 & .20 & .25 & .50 & .30 & .45 & .19 & .21 & .33 & .37 \\
\hline Excitement & .37 & .52 & .47 & .63 & .31 & .43 & .25 & .30 & .39 & .45 \\
\hline $\begin{array}{l}\text { Teacher } \\
\text { effectiveness }\end{array}$ & 1.00 & .57 & .33 & .54 & .31 & 1.00 & .22 & .18 & .16 & .43 \\
\hline $\begin{array}{l}\text { Ability self- } \\
\text { perceptions }\end{array}$ & .57 & 1.00 & .65 & .47 & .41 & .22 & 1.00 & .75 & .52 & .24 \\
\hline $\begin{array}{l}\text { Domain- } \\
\text { difficulty }\end{array}$ & .33 & .65 & 1.00 & .38 & .27 & .18 & .75 & 1.00 & .30 & .27 \\
\hline Value beliefs & .54 & .47 & .38 & 1.00 & .39 & .16 & .52 & .30 & 1.00 & .16 \\
\hline $\begin{array}{l}\text { Academic } \\
\text { performance }\end{array}$ & .31 & .41 & .27 & .39 & 1.00 & .43 & .24 & .27 & .16 & 1.00 \\
\hline
\end{tabular}

Note: All r- values are significant at the .01 level of significance; --: correlations were not significant at the .05 level of significance; the nature of the emotions are positive and negative in the effective teachers group and ineffective teachers group, respectively. 
Table 3. Findings from hierarchical regression analyses for the effects of students' cognitive factors (ability self-perceptions, perceived domain-difficulty, value beliefs) on the impact of their rating of teacher effectiveness on their experienced emotions in lectures of the courses taught by the perceived effective and ineffective teachers

\begin{tabular}{|c|c|c|c|c|c|c|c|c|c|c|c|c|c|c|}
\hline & & & \multicolumn{6}{|c|}{ Perceived effective teachers } & \multicolumn{6}{|c|}{ Perceived ineffective teachers } \\
\hline & Steps & Predictors & $\mathrm{R}^{2}$ & $\begin{array}{l}\mathrm{R}^{2} \mathrm{c} \\
\mathrm{h}\end{array}$ & Fch & $\mathrm{F}$ & beta & $\mathrm{t}$ & $\mathrm{R}^{2}$ & $\mathrm{R}^{2} \mathrm{ch}$ & Fch & $\mathrm{F}$ & beta & $\mathrm{t}$ \\
\hline \multirow[t]{4}{*}{ Happiness } & \multirow[t]{2}{*}{$1 \mathrm{st}$} & \multirow{2}{*}{$\begin{array}{l}\text { Teacher } \\
\text { effectiveness }\end{array}$} & \multirow[t]{2}{*}{.12} & & & \multirow[t]{2}{*}{56.80} & TE. --. & & \multirow[t]{2}{*}{--} & & & \multirow[t]{2}{*}{15.44} & TE. -- & \\
\hline & & & & & & & PA. 29 & 5.58 & & & & & PA. .23 & 2.86 \\
\hline & \multirow[t]{2}{*}{2 nd } & \multirow[t]{2}{*}{ Cognitive factors } & \multirow[t]{2}{*}{.49} & \multirow[t]{2}{*}{.37} & \multirow[t]{2}{*}{96.49} & \multirow[t]{2}{*}{96.45} & PD. 48 & 11.55 & \multirow[t]{2}{*}{.21} & \multirow[t]{2}{*}{.17} & 2.94 & 26.80 & PD..47 & 6.67 \\
\hline & & & & & & & VB. .52 & 10.82 & & & & & VB..23 & 4.40 \\
\hline Satisfaction & $1 \mathrm{st}$ & Teacher & .06 & & & 28.52 & TE. --- & & .17 & & & 81.60 & TE. .49 & 12.86 \\
\hline & & effectiveness & & & & & PA. 17 & 2.68 & & & & & PA. .45 & 6.74 \\
\hline & 2nd & Cognitive factors & .23 & .16 & 27.81 & 13.80 & PD.--- & . & .48 & .30 & 76.73 & 91.31 & PD. .66 & 11.50 \\
\hline & & & & & & & VB. 37 & 6.24 & & & & & VB..37 & 8.48 \\
\hline Pleasure & $1 \mathrm{st}$ & Teacher & .08 & & & 34.76 & TE. --. & & .13 & & & 63.61 & TE. 40 & 9.90 \\
\hline & & effectiveness & & & & & PA. --- & & & & & & РА..22 & 2.80 \\
\hline & 2nd & Cognitive factors & .31 & .23 & 43.93 & 44.54 & PD. .41 & 8.42 & .31 & .17 & 33.26 & 44.62 & PD..39 & 5.60 \\
\hline & & & & & & & VB..24 & 4.23 & & & & & VB. .31 & 6.23 \\
\hline Pride & 1 st & Teacher & .22 & & & 117.40 & TE. 11 & 2.39 & .18 & & & 90.93 & TE. .52 & 13.74 \\
\hline & & effectiveness & & & & & РА. 24 & 4.39 & & & & & РА. .50 & 12.56 \\
\hline & 2nd & Cognitive factors & .45 & .22 & 54.04 & 81.65 & PD. --. & & .50 & .31 & 82.88 & 98.30 & PD. .62 & 11.10 \\
\hline & & & & & & & VB. 40 & 7.93 & & & & & VB. . 47 & 11.01 \\
\hline Encouragement & 1 st & Teacher & .09 & & & 40.05 & TE. 13 & 2.33 & .17 & & & 82.52 & TE. . 44 & 10.30 \\
\hline & & effectiveness & & & & & PA. 14 & 2.09 & & & & & PA. .18 & 2.40 \\
\hline & 2nd & Cognitive factors & .21 & .12 & 20.18 & 26.59 & PD. 29 & 5.32 & .37 & .20 & 43.61 & 59.98 & PD. .33 & 5.20 \\
\hline & & & & & & & VB. 27 & 4.70 & & & & & VB. .38 & 6.86 \\
\hline Confidence & $1 \mathrm{st}$ & Teacher & .08 & & & 34.93 & TE..13 & 2.71 & .27 & & & 149.96 & TE. .61 & 16.90 \\
\hline & & effectiveness & & & & & РA. 26 & 4.55 & & & & & PA. .53 & 8.43 \\
\hline & 2nd & Cognitive factors & .42 & .34 & 77.32 & 71.74 & PD..14 & 3.12 & .57 & .32 & 77.48 & 116.63 & PD. .64 & 11.20 \\
\hline & & & & & & & VB..20 & 3.90 & & & & & VB. . 40 & 9.10 \\
\hline Not anger- anger & $1 \mathrm{st}$ & Teacher & -- & & & 11.22 & TE -- & & .04 & & & 17.55 & TE. .25 & 5.54 \\
\hline & & effectiveness & & & & & РА. 23 & 3.62 & & & & & PA. 34 & 4.90 \\
\hline & 2nd & Cognitive factors & .23 & .23 & 35.18 & 35.18 & PD. -.- & & .21 & .17 & 43.10 & 35.81 & PD. 61 & 8.82 \\
\hline & & & & & & & VB. 39 & 6.65 & & & & & VB. -- & \\
\hline & $1 \mathrm{st}$ & Teacher & .08 & & & 35.79 & ТЕ. 10 & 2.29 & .29 & & & 163.60 & TE. .58 & 13.70 \\
\hline boredom-boredo & & effectiveness & & & & & PA. 12 & 2.36 & & & & & PA. .16 & 2.38 \\
\hline $\mathrm{m}$ & 2nd & Cognitive factors & .50 & .41 & 110.65 & 99.44 & PD. 38 & 9.12 & .41 & .12 & 28.50 & 70.73 & PD..37 & 6.18 \\
\hline & & & & & & & VB..60 & 12.02 & & & & & VB..28 & 4.47 \\
\hline Cheerfulness & $1 \mathrm{st}$ & Teacher & .09 & & & 42.60 & TE. .17 & 3.19 & .04 & & & 17.74 & TE. .23 & 4.80 \\
\hline & & effectiveness & & & & & РА. 36 & 5.64 & & & & & PA. 19 & 2.35 \\
\hline & 2 nd & Cognitive factors & .27 & .18 & 32.82 & 37.83 & PD. 27 & 5.40 & .16 & .12 & 19.42 & 19.62 & PD. .39 & 5.45 \\
\hline & & & & & & & VB. 46 & 7.90 & & & & & VB..19 & 3.52 \\
\hline Interest & $1 \mathrm{st}$ & Teacher & .48 & & & 19.96 & TE. 13 & 2.62 & .22 & & & 115.57 & TE. 49 & 12.14 \\
\hline & & effectiveness & & & & & PA. --. & & & & & & PA. .15 & 2.15 \\
\hline & 2nd & Cognitive factors & .39 & .34 & 75.53 & 64.64 & PD. . 47 & 10.28 & .42 & .19 & 44.98 & 72.27 & PD. .34 & 5.60 \\
\hline & & & & & & & VB. 29 & 5.52 & & & & & VB. .34 & 7.48 \\
\hline & $1 \mathrm{st}$ & Teacher & .11 & & & 53.44 & TE. --. & & .05 & & & 21.64 & TE. .28 & 6.22 \\
\hline irritation-irritatio & & effectiveness & & & & & РА. 29 & 5.24 & & & & & PA. .38 & 5.51 \\
\hline $\mathrm{n}$ & 2nd & Cognitive factors & .42 & .30 & 70.85 & 73.59 & PD. 10 & 2.15 & .25 & .20 & 53.98 & 45.11 & PD...66 & 9.88 \\
\hline & & & & & & & VB. 48 & 9.80 & & & & & VB. -- & \\
\hline Hope & $1 \mathrm{st}$ & Teacher & .13 & & & 59.60 & TE. --- & & .29 & & & 169.38 & TE. .56 & 15.26 \\
\hline & & effectiveness & & & & & PA. -.. & & & & & & PA. .13 & 2.20 \\
\hline
\end{tabular}




\begin{tabular}{|c|c|c|c|c|c|c|c|c|c|c|c|c|c|c|}
\hline & 2nd & Cognitive factors & .45 & .32 & 79.25 & 83.11 & PD. 19 & 4.50 & .53 & .23 & 65.15 & 111.70 & PD..37 & 6.88 \\
\hline & & & & & & & VB. .63 & 12.57 & & & & & VB..34 & 8.23 \\
\hline \multirow[t]{4}{*}{ Competence } & \multirow[t]{2}{*}{$1 \mathrm{st}$} & \multirow{2}{*}{$\begin{array}{l}\text { Teacher } \\
\text { effectiveness }\end{array}$} & \multirow[t]{2}{*}{.12} & & & 58.72 & TE. -.- & & \multirow[t]{2}{*}{.05} & & & \multirow[t]{2}{*}{21.10} & TE. 29 & 7.60 \\
\hline & & & & & & & PA. 34 & 5.21 & & & & & РA. 35 & 5.04 \\
\hline & \multirow[t]{2}{*}{ 2nd } & \multirow[t]{2}{*}{ Cognitive factors } & \multirow[t]{2}{*}{.51} & \multirow{2}{*}{.39} & \multirow[t]{2}{*}{106.34} & \multirow[t]{2}{*}{16.09} & PD. -- & & \multirow[t]{2}{*}{.41} & \multirow[t]{2}{*}{.36} & \multirow[t]{2}{*}{80.53} & \multirow[t]{2}{*}{68.40} & PD..40 & 6.50 \\
\hline & & & & & & & VB. 63 & 13.26 & & & & & VB..61 & 13.11 \\
\hline \multirow[t]{4}{*}{ Calmness } & \multirow[t]{2}{*}{$1 \mathrm{st}$} & \multirow{2}{*}{$\begin{array}{l}\text { Teacher } \\
\text { effectiveness }\end{array}$} & \multirow[t]{2}{*}{--} & & & \multirow[t]{2}{*}{11.56} & TE. -- & & \multirow[t]{2}{*}{.06} & & & \multirow[t]{2}{*}{27.40} & TE. .25 & 5.37 \\
\hline & & & & & & & PA. .14 & 2.20 & & & & & PA. -- & \\
\hline & \multirow[t]{2}{*}{2 nd } & \multirow[t]{2}{*}{ Cognitive factors } & \multirow[t]{2}{*}{.25} & \multirow[t]{2}{*}{.22} & 40.84 & 34.04 & PD. .19 & 3.86 & .10 & .042 & 18.46 & 23.50 & PD. -- & \\
\hline & & & & & & & VB. .18 & 3.37 & & & & & VB..20 & 4.29 \\
\hline Anxiety & $1 \mathrm{st}$ & Teacher & .06 & & & 27.65 & TE. .-- & & -- & & & 8.28 & TE. -- & \\
\hline & & effectiveness & & & & & PA. .-- & & & & & & РA. .35 & 5.28 \\
\hline & 2nd & Cognitive factors & .34 & .33 & 58.04 & 51.81 & PD. .50 & 10.55 & .18 & .18 & 25.74 & 25.74 & PD. .64 & 9.45 \\
\hline & & & & & & & VB. .18 & 52.88 & & & & & VB..16 & 2.38 \\
\hline Enthusiasm & $1 s t$ & Teacher & .15 & & & 68.19 & TE. 24 & 4.72 & .20 & & & 102.20 & TE. .55 & 13.45 \\
\hline & & effectiveness & & & & & PA. 37 & 6.61 & & & & & PA. .53 & 7.47 \\
\hline & 2 nd & Cognitive factors & .33 & .19 & 37.62 & 50.02 & PD..16 & 3.96 & .40 & .20 & 45.57 & 68.30 & PD. .45 & 7.33 \\
\hline & & & & & & & VB. .54 & 9.96 & & & & & VB. .47 & 10.15 \\
\hline Excitement & $1 \mathrm{st}$ & Teacher & .14 & & & 69.14 & TE. .-. & & .17 & & & 86.30 & TE. .52 & 13.17 \\
\hline & & effectiveness & & & & & PA. -.. & & & & & & PA. .48 & 7.80 \\
\hline & 2 nd & Cognitive factors & .53 & .39 & 108.67 & 112.28 & PD. .23 & 5.87 & .65 & .27 & 66.77 & 82.28 & PD. .49 & 9.40 \\
\hline & & & & & & & VB. 59 & 12.78 & & & & & VB. .51 & 11.66 \\
\hline
\end{tabular}

Note: $\mathrm{TE}=$ Rating teacher effectiveness; PA. = Ability self-perceptions; PD. = Perceived domain-difficulty; VB. $=$ Value beliefs; All F-and Fch- values are significant at the .01 level of significance; t- values $>2.40$, are significant at the .01 level of significance; $t$ - values $\leq 2.40$, are significant at the .05 level of significance; $--=$ variable was not entered in the analysis because there was non significant correlations at the .05 level of significance; --- $=$ nonsignificant contribution in the formation of the emotion. 